Canadian Journal of Fisheries and Aquatic Sciences

Canadian Science Publishing

Journal canadien des sciences halieutiques et aquatiques

\title{
Lack of recreational fishing compliance may compromise effectiveness of Rockfish Conservation Areas in British Columbia
}

\begin{tabular}{|r|l|}
\hline Journal: & Canadian Journal of Fisheries and Aquatic Sciences \\
\hline Manuscript ID & cjfas-2015-0205.R1 \\
\hline Manuscript Type: & Article \\
\hline Complete List of Authors: & $\begin{array}{l}\text { Haggarty, Dana ; University of British Columbia, Zoology; } \\
\text { Martell, Steven; International Pacific Halibut Commission, } \\
\text { Shurin, Jonathan; UCSD, }\end{array}$ \\
\hline Keyword: & $\begin{array}{l}\text { Rockfish Conservation, Compliance Measurement, Recreational Fishing, } \\
\text { Fishing Effort, Marine Protected Area }\end{array}$ \\
\hline \multicolumn{2}{|c}{} \\
\hline
\end{tabular}

\section{SCHOLARONE \\ Manuscripts}


2 Lack of recreational fishing compliance 3 may compromise effectiveness of Rockfish 4 Conservation Areas in British Columbia.

6 Dana R. Haggarty, Biodiversity Research Centre, University of British Columbia, 112-2212

7 Main Mall Vancouver, BC, V6T 1Z4, Canada

8 haggarty@zoology.ubc.ca;

9 Steve J.D. Martell, UBC Fisheries Centre, 2202 Main Mall, Vancouver, BC, V6T 1Z4 Canada

10 Present address: International Pacific Halibut Commission, 2320 West Commodore Way, Suite

11300 , Seattle, WA, 98199-1287, USA

12 stevem@iphc.int;

13 Jonathan B. Shurin, University of California at San Diego, 9500 Gilman Dr. La Jolla, CA 92093,

14 USA

15 jshurin@ucsd.edu 
D.R. Haggarty, S.J.D. Martell \& J.B. Shurin

\section{Abstract}

20 Compliance with spatial fishing regulations (e.g. marine protected areas, fishing closures) is one

21 of the most important, yet rarely measured, determinants of ecological recovery. We used aerial

22 observations of recreational fishing events from creel surveys before, during and after 77

23 Rockfish Conservation Areas (RCAs) were established in British Columbia, Canada. There was

24 no evidence of a change in fishing effort in $83 \%$ of the RCAs, and effort in five RCAs increased

25 after establishment. Fishing effort in open areas adjacent to the RCAs declined with time and

26 was higher than effort in the RCAs in all three years. Next, we used compliance data for 105

27 RCAs around Vancouver Island to model the drivers of compliance. Compliance was related to

28 the level of fishing effort around the RCA, the size and perimeter-to-area ratio of RCAs,

29 proximity to fishing lodges and the level of enforcement. Non-compliance in RCAs may be

30 hampering their effectiveness and impeding rockfish recovery. Education and enforcement

31 efforts to reduce fishing effort inside protected areas are critical to the recovery of depleted fish

32 stocks.

34 Keywords: Rockfish Conservation, Compliance Measurement, Recreational Fishing, Fishing

35 Effort, Marine Protected Area. 
D.R. Haggarty, S.J.D. Martell \& J.B. Shurin

\section{Introduction}

38 Jurisdictions around the world are increasingly using spatial management (e.g., marine reserves,

39 fishing closures) to conserve and restore overfished populations (Hamilton et al. 2010, Parker et

40 al. 2000, Yamanaka and Logan 2010, Yoklavich 1998). The effectiveness of marine reserves and

41 marine protected areas (MPAs) depends on reducing or eliminating fishing pressure within their

42 boundaries (Ainsworth et al. 2012, Gaines et al. 2010, Kritzer 2004, Sethi and Hilborn 2008).

43 Reserves with high rates of non-compliance show limited recovery of fish communities

44 (Ainsworth et al. 2012, Campbell et al. 2012, Kritzer 2004, McClanahan et al. 2009), and

45 compliance information can predict the recovery of fish biomass without incorporating any

46 reserve design factors (Bergseth et al. 2013). Furthermore, a global study of marine reserves

47 identified enforcement as one of five key features that influenced effectiveness (Edgar et al.

48 2014). Similarly, compliance levels reported by resource users and population density were the

49 best predictors of reserve effectiveness in a study of 56 tropical marine reserves (Pollnac et al.

50 2010). However, despite their importance for recovery, compliance rates are rarely quantified

51 (Sethi and Hilborn 2008, Smallwood and Beckley 2012), and when compliance is measured,

52 most data are qualitative (anecdotal or expert opinion) and direct empirical observations are rare

53 (Bergseth et al. 2013).

54 Non-compliance is prevalent where it has been studied. For example, Smallwood and Beckley

55 (2012) found that 8 to $12 \%$ of recreational boats were fishing in closed zones in Australian

56 MPAs. Ten percent of recreational fishers involved in a questionnaire using the random response

57 technique in Australia admitted to fishing in closed areas (Arias and Sutton 2013). Williamson et

58 al. (2014) used the density of derelict fishing line as a proxy of recreational compliance in no-

59 take zones in the Great Barrier Reef Marine Park and found that no take areas had 30\% of the 
D.R. Haggarty, S.J.D. Martell \& J.B. Shurin

60 fishing effort of surrounding open areas (Williamson et al. 2014). Compliance can also change

61 over time. For instance in Mexico, travel to marine reserves by fishermen declined shortly after a

62 reserve was implemented, but compliance declined within four years as fishermen learned that

63 there was no enforcement (Fujitani et al. 2012).

64 The environmental and social drivers that influence compliance in marine reserves are a critical

65 research frontier for the implementation of more effective MPAs (Bergseth et al. 2013). Reserve

66 design features such as size and shape may influence compliance (Gaines et al. 2010, Kritzer

67 2004, Read et al. 2011). Fishing is often concentrated around the edge of a reserve; therefore

68 larger MPAs with lower perimeter-to-area ratios should have lower fishing rates due to lower

69 straying rates along their perimeters (Read et al. 2011). The location of reserves may also

70 influence compliance as fishing often decreases with the distance to port and is greater with

71 closer proximity to towns, fishing piers and boat ramps (Read et al. 2011, Stelzenmüller et al.

72 2008). Involving stakeholders in the planning process of conservation areas may also affect

73 compliance and enhance MPA effectiveness (Pollnac et al. 2010). However, few studies have

74 actually tested these assumptions with empirical measurements of compliance (Bergseth et al.

75 2013, Pollnac et al. 2010).

76 Here we examine recreational fishing compliance in Rockfish Conservation Areas (RCAs), in

77 British Columbia (BC), Canada. In response to conservation concerns associated with a sharp

78 decline in inshore rockfishes catches throughout the 1990s in the Northeast Pacific, Fisheries and

79 Oceans Canada (DFO) implemented a system of 164 Rockfish Conservation Areas. RCAs were

80 established between 2004 and 2007 and prohibit commercial and recreational hook and line

81 fisheries and bottom trawl fisheries; although aboriginal fishing for food, social and ceremonial

82 purposes, as well as fisheries with minimal impact on rockfishes are permitted (see Yamanaka 
D.R. Haggarty, S.J.D. Martell \& J.B. Shurin

83 and Logan 2010). The BC commercial fishery exhibits good compliance with the RCAs as a

84 result of onboard and electronic fishery monitoring by Global Positioning System (GPS)

85 technology and observers (unpublished data, N. Olson, Groundfish Data Unit, DFO, Nanaimo

86 BC, 2015). Compliance by the recreational fishery has yet to be assessed, although anecdotal

87 observations indicate that fishing in closed areas persists and that recreational compliance might

88 be low (Marliave and Challenger 2009). The purpose of our study was to assess and identify

89 drivers of recreational compliance with RCAs. We aimed to answer two questions: 1. Has the

90 spatial pattern of recreational fishing effort changed in the RCAs since they were established?

91 and 2. What geographic factors affect variation in compliance among RCAs?

\section{Materials and Methods}

93 Study area context

94 Rockfish Conservation Areas (RCAs) were implemented in BC as part of a larger Rockfish

95 Conservation Strategy. Inshore rockfishes include six species of the genus Sebastes (S. caurinus,

96 S. maliger, S. melanops, S. nebulosus, S. nigrocinctus, and S. ruberrimus) that are found on

97 shallow $(<200 \mathrm{~m})$ rocky reefs. Although RCAs are not considered MPAs because they are

98 fisheries closures rather than permanently legislated protected areas (Robb et al. 2011), they do

99 prohibit commercial and recreational fisheries that target or lead to a significant bycatch of

100 rockfishes (Yamanaka and Logan 2010). Recreational (e.g., through the Sport Fish Advisory

101 Board) and commercial fishers as well as conservationists, First Nations and the public were

102 consulted in the designation of the RCAs (Yamanaka and Logan 2010). Although the protection

103 targets were ambitious $-30 \%$ of rockfish habitat in "inside" waters east of Vancouver Island,

104 and $20 \%$ of outer coast habitats - attempts were made to minimize socio-economic impacts on 
D.R. Haggarty, S.J.D. Martell \& J.B. Shurin

105 recreational and salmon troll fisheries. Other considerations in the designation of the RCAs

106 included rockfish habitat, the ease of monitoring and enforcement (Yamanaka and Logan 2010).

107 Rockfishes are targeted by recreational fishers and caught as bycatch while angling for salmon or

108 bottom fish such as halibut and lingcod (Zetterberg et al. 2012b). The contribution of recreational

109 fisheries to rockfish mortality varies by region. In 2011, recreational fishers caught $90 \%$ of the

110 estimated 35,000 inshore rockfishes caught in the Strait of Georgia, compared to 35\% of 60,000

111 fish and $8 \%$ of 93,000 on the west coast and northeast coast of Vancouver Island, respectively

112 (recreational data from D. O'Brien, Fisheries and Oceans Canada; commercial data from N.

113 Olsen, Fisheries and Oceans Canada). In addition to designating RCAs, Fisheries and Oceans

114 Canada reduced recreational daily bag limits from ten to five rockfishes in outside waters and

115 from five to one rockfish on the inside as part of the rockfish conservation strategy (Yamanaka

116 and Logan 2010).

117 We focused our analysis on Vancouver Island and the Strait of Georgia. Vancouver Island is

118 separated from the mainland coast by the inland waters of the Strait of Georgia, Johnstone Strait

119 and Queen Charlotte Strait, locally called "inside” waters. BC's two largest population centers,

120 Vancouver and Victoria, as well as numerous smaller towns border the Strait of Georgia. The

121 northeast and west coasts of Vancouver Island are much more sparsely populated but have

122 numerous recreational fishing lodges. Of the 164 RCAs, 144 are found in southern BC and 129

123 of these are in inside waters (Figure 1).

124 Data collection and preparation

125 Fisheries and Oceans Canada monitors the marine recreational fishery in BC using Creel Surveys

126 (English et al. 2002). The creel survey has two components: (1) dockside interviews, where 
D.R. Haggarty, S.J.D. Martell \& J.B. Shurin

127 fishers are asked where they fished, what they caught, kept and released, and how long they

128 fished; and (2) effort counts via aerial surveys along pre-defined flight paths timed to cover

129 major periods of fishing activity. Planes fly at an altitude of 150-300 $\mathrm{m}$ to allow for a broad

130 range of vision and easy identification of vessel type and activity. Between six and ten flights per

131 month are completed during the peak fishing season (Zetterberg et al. 2012a). An observer

132 counts all boats and uses binoculars to determine if they are actively fishing (lines in the water)

133 or not (traveling or engaged in other activities such as trap fishing). The observer marks the

134 estimated geographic location of the boats on maps of the study area. The number of boats are

135 summed by management area and used in conjunction with dockside interviews to estimate the

136 total sport-fish effort and the number of salmon and groundfish caught in the sport fishery (i.e.

137 Zetterberg, Watson et al. 2012). However, the data have not previously been digitized or geo-

138 referenced with the RCA network to assess compliance.

139 We used the spatial information from the creel survey over-flights to assess recreational

140 compliance in the RCAs. We digitized and georeferenced creel survey maps for the Northern and

141 Southern Strait of Georgia, Queen Charlotte Sound and the northwest coast of Vancouver Island

142 using major coastal features and management area boundaries in ArcGIS 10.1 (ESRI 1999-

143 2012). We recorded the root mean squared (RMS) error (ESRI 2008), a measure of the

144 difference between known locations and points that have been interpolated or digitized, for each

145 image. The fishing observations were then manually digitized for each survey date between May

146 and September, when $85 \%$ of the sport-fish effort in BC occurs (Zetterberg et al. 2012b). To

147 avoid bias, RCAs were not displayed in the GIS project while we digitized fishing observations.

148 We digitized data for the Strait of Georgia for 2003, 2007 and 2011, while data for the northeast

149 and west coasts of Vancouver Island were only available for 2011. Only RCAs that fall within 
D.R. Haggarty, S.J.D. Martell \& J.B. Shurin

150 view of the survey route were used in our analyses (Figure 1). Since the flight pattern near one

151 RCA, Desolation Sound, changed between 2007 and 2011, it was dropped from the temporal

152 analysis.

153 Temporal Analysis

154 We used data from 2003 to represent fishing effort prior to establishment since the RCAs were

155 designated between 2004 and 2006. The Creel Survey estimates of effort for 2003, 156,670 boat

156 trips, was the median value from 1999-2003 (Zetterberg et al. 2012b). The first year all RCAs

157 were in place was 2007 and 2011 is at least five years after RCA establishment. The temporal

158 analysis is limited to the Strait of Georgia.

159 We compared the effort in 77 RCAs in the Strait of Georgia between 2003, 2007 and 2011.

160 Recreational Fishing effort is higher on weekends than on weekdays so the creel survey is

161 stratified by type of day (English et al. 2002). Following the methods used in English et al.

162 (2002) we normalized effort in and around RCAs by the type of day (weekday vs. weekend) as

163 well as the number of flights per month in order to compare effort between years (Equation 1).

164 The number of flights per month varied among years. To normalize the sampling effort for each

165 RCA in each year, the total boat observations by day were multiplied by the total number of each

166 day of that type in each month (i.e. 19, 20 or 21 weekdays and 9, 10 or 11 weekend days) to

167 yield the number of boat-days. We calculated the average monthly boat observations for each

168 day type by dividing by the number of surveys taken on that day type and then added the average

169 of the weekday and weekend together for an estimate of the monthly boat observations (per

170 RCA, per year). We then summed the observations for all months (May-September) to get an

171 estimate of fishing effort in boats/year during the periods of observation (Equation 1). 
D.R. Haggarty, S.J.D. Martell \& J.B. Shurin

$$
\bar{B}_{M}^{R}=\sum_{t}^{2}\left(\frac{\left(\sum B_{M t}^{\mathrm{R}} * D_{M t}\right)}{F_{M t}}\right)
$$

(Equation 1)

173 Where:

$\mathrm{B}=$ Boats (effort)

$\mathrm{M}=$ Month

$\mathrm{t}=$ Day type $(1=$ weekday, $2=$ weekend)

$\mathrm{D}=\quad$ Days per month

$\mathrm{R}=\mathrm{RCA}$

$\mathrm{F}=\quad$ Flights (surveys)

175 In order to control for overall changes in fishing effort in the vicinity of the RCAs, we also

176 calculated the effort in a one kilometer-wide buffer strip around each RCA. In GIS, we

177 intersected the fishing observations with the RCAs and a one kilometer-wide buffer strip around

178 each RCA. To compare effort among RCAs and between RCAs and buffers, we calculated an

179 effort density by dividing the effort by the area $\left(\mathrm{km}^{2}\right)$ of the RCA and the buffer.

180 To analyse the relationship between fishing effort and protection status among years, we used a

181 linear mixed effects model with a Gaussian distribution in the program R (R Development Core

182 Team 2008) and the package nlme (Pinheiro et al. 2012). Because our data were highly skewed, 
D.R. Haggarty, S.J.D. Martell \& J.B. Shurin

183 we used a $\log (\mathrm{x}+1)$ data transformation to normalize variance (Zar, 1986). Year $(2003,2007$ and

184 2011), treatment (RCA vs. Buffer), and the interaction of year and treatment were entered as

185 fixed effects and RCA was a random factor. Visual inspection of the residual plots did not reveal

186 any obvious deviations from homoscedactisity or normality after transformation. The model was

187 estimated using the log-likelihood method so that models could be compared using the Aikake

188 Information Criterion (AIC) (Zurr et al. 2009). The full model was compared to reduced models

189 with only Year, Treatment, and Year + Treatment without the interaction. An interaction

190 between year and treatment indicates that the fishing effort differential between protected and

191 unprotected areas varied over time. A contrast between 2003 vs. 2007 and 2011 indicates an

192 effect of fisheries closure on effort. The final model was fit using restricted maximum likelihood

193 estimation (REML) (Zurr et al. 2009).

194 Next, we identified which RCAs had experienced a change in fishing effort over time. We used 195 analysis of variance on the monthly $\log (\mathrm{x}+1)$ effort density (May-September) for each RCA 196 with year $(2003,2007,2011)$ as the independent variable. We adjusted the critical $P$ value for

197 multiple comparisons with the Bonferroni correction. When significant differences among years

198 were found, we used a pairwise Tukey HSD test to determine which years differed.

199 To examine changes in effort on a finer spatial scale than the RCA, we plotted spatial fishing

200 effort using the Kernel Density tool in ArcGIS 10.1 (ESRI 1999-2012) with a grid cell size of

$201100 \times 100 \mathrm{~m}$ and a one kilometer search radius. The Kernel Density tool calculates a magnitude

202 effort per unit area from point features using a quadratic function to fit a smoothly tapered

203 surface to each point (ESRI 2012). To turn these kernel density plots into a probability density,

204 we divided effort in each cell in the kernel density plot in each year by the total number of

205 observations used to calculate the plot using the Raster Calculator tool (Abbott and Haynie 
D.R. Haggarty, S.J.D. Martell \& J.B. Shurin

206 2012). Once the density plots have been normalized using this method, the volume under the

207 entire density plot equals 1 and the value in each grid cell is the probability of fishing effort.

208 Abbott and Haynie (2012) used this method to compare fishing effort from trawling in and

209 around two fishing closures in Alaska. We compared the density probabilities among time

210 periods using the raster calculator to subtract the effort between years and mapped the results.

211 We also calculated the standardized effort for each Pacific Fisheries Management Area (PFMA,

212 Figure 1) using Equation 1. We compared the proportion of the summed effort in all RCAs in a

213 Pacific Fishery Management Area (PFMA) to the total effort in each area and compared this

214 proportion among years with a Chi-square contingency table analysis.

\section{Factors Affecting RCA Compliance}

216 We explored the geographic factors that affect recreational compliance with a Generalized

217 Additive Model (GAM) using the package mgev (Wood 2011) in R (R Development Core Team

218 2008). We used a Gaussian distribution and Identity link function to predict fishing effort in

2192011 in 105 RCAs around Vancouver Island that could be observed from the over-flights. We

220 omitted one extremely small RCA (Hardy Bay) $\left(0.1 \mathrm{~km}^{2}\right)$. We calculated the fishing effort

221 probability using the normalized kernel density method described above. We made separate

222 probability plots for each region surveyed in 2011. Because we did not compare among years in

223 this analysis, we did not need to standardize the data using Equation 1. We summed the fishing

224 probability over the entire RCA as well as a two kilometer-wide buffer area around each RCA.

225 The dependent variable in the GAM model was the total probability of effort in each RCA

226 divided by the area of the RCA. 
D.R. Haggarty, S.J.D. Martell \& J.B. Shurin

227 Explanatory variables included the distance from each RCA to the closest city (population

$228>5,000)$ and to the closest fishing lodge; the total probability of fishing effort in the buffer

229 divided by the area of the buffer; the estimated rockfish catch in each PFMA; the human

230 population within a $25 \mathrm{~km}$ radius of each RCA; RCA size and the perimeter-to- area ratio; the

231 number of hours patrolled by conservation officers by geographic region; and geographic region

232 as a factor (Table S1). We did not include the distance to other coastal features such as the

233 closest community or boat ramps because of the low variability among RCAs in these features.

234 The mean distance between RCAs and the closest community and boat ramp was $7.1 \mathrm{~km}$ (SD

235 6.7) and $6.8 \mathrm{~km}$ (SD 6.7), respectively. We used a rank transformation on the dependent variable

236 and many of the independent variables (effort outside, enforcement, population and RCA Area)

237 because they had highly skewed distributions (Table S1). In order to identify the explanatory

238 variables that have a significant influence on the fishing effort density, we used the package

239 MuMIn (Barton 2013) in R (R Development Core Team 2008) to compare all sub-models of the

240 full model and to rank the sub-models using the AICc. The model with the lowest AICc value is

241 the best model and the explanatory variables retained in this model can be assumed to have a

242 significant influence on the fishing-effort density in the RCAs (Stelzenmüller et al. 2008).

243 Finally, we tested the effort density in RCAs among regions and among park type (i.e., RCAs

244 that are in a National Park, Provincial Park, Provincial Ecological Reserve, or not a park) using a

245 Kruskal-Wallis test.

246 Rockfish Catch in RCAs

247 It is not possible to directly measure the rockfish catch taken from RCAs from the spatial data

248 since creel interviews are conducted over regions at broader spatial resolution. In order to

249 estimate the fisheries take from the RCAs, we calculated the total recreational effort for each 
D.R. Haggarty, S.J.D. Martell \& J.B. Shurin

250 Pacific Fisheries Management Area (PFMA, Figure 1) using Equation 1. We then calculated the

251 fraction of fishing effort in each PFMA that occurred in RCAs and applied this proportion to the

252 creel survey estimates of total rockfish caught per PFMA derived from the overflight data and

253 dockside interviews (data from D. O'Brien, South Coast Management, DFO). We assumed that

254 rockfish could be caught anywhere in the PFMA, regardless of habitat features such as depth or

255 bottom cover, and that catch rates are equivalent between RCAs and unprotected areas. This is a

256 conservative estimate of take from the RCAs since it is likely that a greater proportion of the

257 rockfish catch would be caught in suitable rockfish habitat, and therefore in the RCAs.

\section{Results}

259 Data Compilation

260 The number of images georeferenced by region and year, along with the positional accuracy

261 (Root Mean Squared (RMS) error) is shown in Table 1. The positional accuracy (15.9 to $30.1 \mathrm{~m}$

262 error) was small in comparison to the size of an RCA (Table 1). The fishing events from the

263 Southwest Coast of Vancouver Island in 2011 were supplied digitally by Fisheries and Oceans

264 Canada without an estimate of positional accuracy. The dataset contains over 65,000 recreational

265 fishing observations.

266 Temporal Analysis

267 Effort in both the 77 RCAs and the one-kilometer-wide buffers declined with time between

268 2003, 2007 and 2011 (Figure 2). This corresponds with the declining trend that is seen for the

269 fishing effort in the whole Strait of Georgia (Figure S1). The linear mixed-effect model with the

270 lowest AIC value was the full model with fixed effects for year, protection status, and the

271 interaction of year and protection status (Table 2). The treatment effect is the strongest, with 
D.R. Haggarty, S.J.D. Martell \& J.B. Shurin

272 greater effort outside of the RCAs than inside in all time periods, including 2003 before the

273 RCAs were established. The interaction between year and treatment indicates that the difference

274 between effort in and outside of the RCAs declined with time (Figure 2).

275 We also compared the proportion of effort in the RCAs to the total effort in each management

276 area (PFMA) by year (Figure 3). PFMA 15 is not shown due to a change in the flight pattern

277 over one large RCA. A Chi-square test showed no evidence of change in the proportional effort

278 in the RCAs by year (Figure 3).

279 We used estimates of monthly effort per year for each RCA (Table 3, Figure S2, Table S2) and

280 the kernel density effort maps (Figure 4) to examine effort in individual RCAs. There was no

281 evidence of a change in effort in most RCAs (83\%) amongst the three years. Thirty RCAs had

282 effort greater than 0.5 boats per $\mathrm{km}^{2}$ in all years. Effort in two RCAs increased between 2003 to

2832007 and effort increased in three different RCAs between 2007 and 2011. Deepwater Bay and

284 Oyster Bay had greater effort 2007 than 2003 and Copeland and Darcy Island had greater effort

285 in 2011 than in 2007. Effort in Deepwater Bay declined in 2011 as compared to 2007 (Figure 4).

286 Effort declined significantly in five RCAs in both time periods and in three other RCAs in 2007

287 or 2011 (Table 3). Fishing effort in four RCAs south of Victoria declined in one or both years

288 (Figure 4). Not all RCAs are fished. Fourteen RCAs had no effort in any year and 20 others had 289 only very low effort in all three years. Offshore RCAs, Ajax, Halibut and McCall banks, had no 290 effort in any year (Figure 4).

291 Factors Affecting RCA Compliance

292 The best fit GAM model to predict effort in the RCAs retained the fishing effort density in the

293 buffer, the distance to fishing lodges, the amount of enforcement effort (patrol hours), the area of 
D.R. Haggarty, S.J.D. Martell \& J.B. Shurin

294 the RCA and the perimeter-to-area ratio. Distance to cities, population within $25 \mathrm{~km}$ and the

295 level of rockfish catch in the PFMA were not included in the best model (Table 4, Figure 6).

296 Effort in the RCA generally increased with the amount of fishing effort in the buffer. Fishing

297 effort also increased in proximity to fishing lodges. Fishing effort declined with distance to a

298 lodge up to around $15-20 \mathrm{~km}$, beyond which the relationship was flat. Many RCAs, particularly

299 in the southern Strait of Georgia, are not near any fishing lodge (Figure 5). Larger RCAs also

300 experienced greater fishing effort per unit area than smaller RCAs. Effort also increased with the

301 ratio of perimeter-to-area, although the relationship reaches a maximum and flattens out. The

302 influence of enforcement is complex and non-linear, perhaps because the patrol hours spent in a

303 geographic region is a coarse estimate that may not realistically represent the actual amount of

304 time an RCA in a region was enforced. Region was not a significant factor and was not retained

305 in the model despite a significant difference between in effort between Mid-Strait of Georgia

306 (MSOG), where many RCAs are not fished, and the Campbell River (CR) and Queen Charlotte

307 Strait regions (Figure 6). We found no difference in effort density among park types with a

308 Kruskal-Wallis test $(\mathrm{K}=1.4, \mathrm{df}=3, \mathrm{p}=0.7)$.

310 The fishing effort in the RCAs is quite low compared to the effort in each management area

311 (PFMA) $(<5 \%$ in most PFMAs, Figure S3). However, one large RCA on NW Vancouver Island

312 (PFMA 27), Topknot, experiences 10\% of the fishing effort in the region (Figure S3). We

313 estimate 175 rockfishes were fished from the Topknot RCA in PFMA 27 in 2011 (Figure S3).

314 Rockfish Conservation Areas near Nanaimo (PFMA 17) and in the Southern Gulf Islands

315 (PFMA 18) experienced eight and six percent of the effort respectively. We estimate that RCAs 
D.R. Haggarty, S.J.D. Martell \& J.B. Shurin

316 in PFMA 17 and 18 contributed almost 720 and 370 rockfish, respectively, to the fishery in

317 2011, although this catch was spread over numerous RCAs.

\section{Discussion}

319 Compliance with recreational fishing regulations in the RCAs in BC is low. Of the 77 RCAs

320 studied in the Strait of Georgia, 79\% still showed some level of fishing effort after the

321 establishment of the RCAs and effort in five RCAs even increased (Table S2). Compliance was

322 influenced by the amount of fishing effort adjacent to the RCA, the proximity to fishing lodges,

323 the size and perimeter-to-area ratio and enforcement. A lack of compliance in MPAs may inhibit

324 population recovery and impair reserve effectiveness (Bergseth et al. 2013, Edgar et al. 2014,

325 Fujitani et al. 2012); however, the effectiveness of the RCA network remains unknown. Our

326 results indicate that the effectiveness of the RCA network at promoting population recovery may

327 be compromised by lack of compliance.

328 Only eight of 77 RCAs decreased in one or both years relative to 2003, although effort adjacent

329 to the RCAs declined with time. Recreational fishing effort in the Strait of Georgia is driven by

330 Chinook and Coho Salmon catches and has steadily declined since the 1980s when over 500,000

331 boat trips per summer were estimated by the creel survey. Recreational effort in the whole Strait

332 of Georgia declined between 2003 and 2011 as a result of declining salmon stocks (Zetterberg et

333 al. 2012b). A decline in recreational effort cannot be attributed to the creation of the RCAs. If the

334 recreational fishery increases with improvements in salmon stocks, RCAs may experience

335 greater levels of fishing if compliance is not improved.

336 Fishing effort was lower in the RCAs than in unprotected reference buffer areas; however, effort

337 in the area of the RCAs was also lower before they were established. Some RCAs were not 
D.R. Haggarty, S.J.D. Martell \& J.B. Shurin

338 fished recreationally in any year and a lack of effort in those RCAs is not evidence of a change in

339 fishing behaviour as a result of spatial management. The RCAs were designated in consultation

340 with the sport fishing community and the boundaries of the RCAs were designed to minimize

341 effects on the sport fishery by leaving popular salmon fishing locations open (Granek et al. 2008,

342 Yamanaka and Logan 2010). Involving the resource users in the implementation of management

343 actions is thought to enhance conservation success and fishery management (Granek et al. 2008).

344 Consultation with recreational fishers may not have been effective in this case as awareness

345 about the RCAs appears to be low. If the most popular fishing spots are also the prime rockfish

346 habitat, then the RCAs may not include the most important areas for promoting population

347 recovery.

348 The greatest factor influencing compliance among the RCAs is the amount of fishing adjacent to

349 the RCA, followed by the size of the RCA, with larger RCAs having greater effort per unit area

350 than smaller RCAs. This contrasts with results of Kritzer (2004) who found greater compliance

351 in large than small MPAs. Kritzer's data highlighted the importance of the perimeter-to-area

352 ratio as people tend to fish near the boundaries of MPAs (Kritzer 2004). RCAs with greater

353 perimeter-to-area ratios are more at risk to fishing; however this relationship levels off at

354 intermediate perimeter-to-area ratios. RCAs in close proximity to fishing lodges (within 15 to 20

$355 \mathrm{~km}$ ) have lower compliance. Although fishing effort is often higher closer to towns (Read et al.

356 2011, Stelzenmüller et al. 2008) the proximity to cities and the population within $25 \mathrm{~km}$ of the

357 RCA were not significant factors. Our model indicates that non-compliance is more likely if

358 there is greater effort in the region, and if the RCAs are a large "target" with a long boundary.

359 Fishers are likely incidentally fishing in RCAs rather than actively targeting them, particularly

360 since the rockfish catch did not influence compliance rates. Recreational fishing patterns in BC 
D.R. Haggarty, S.J.D. Martell \& J.B. Shurin

361 are not driven by rockfish since the primary target of most recreational fishers in BC is salmon

362 and the most sought-after groundfish are halibut and lingcod (Fisheries and Oceans Canada

363 2012). Fishers may not, therefore, be aware of the regulations or locations of RCA, despite the

364 fact that rockfishes are caught incidentally in these other fisheries which are prohibited in RCAs.

365 The number of patrol hours by region was also a significant predictor in the model, although the

366 patterns are complex and non-linear. RCAs near Victoria are relatively well patrolled and have

367 good compliance, despite high fishing effort adjacent to the RCAs. Conversely, one of the most

368 heavily fished RCAs, Topknot, on the remote northwest coast of Vancouver Island, is close to

369 fishing lodges and is rarely patrolled. These patterns might reflect the dense population near

370 Victoria vs. the sparsely populated northwestern coast of Vancouver Island, although population

371 within $25 \mathrm{~km}$ of an RCA did not influence compliance. Pollnac et al. (2010) found that reserves

372 close to dense populations were more effective than those near lower populations, perhaps due to

373 greater vigilance by reserve neighbours. Their findings did, however, suggest that compliance is

374 related to a range of conditions such as education, formal consultation, monitoring by

375 community, and clearly defined boundaries rather than to just the level of enforcement per se

376 (Pollnac et al. 2010). Additional enforcement would likely increase compliance in RCAs as

377 fishers are able to adjust to levels of enforcement (Fujitani et al. 2012). For example, effort in

378 one RCA, increased between 2003 and 2007, but declined between 2007 and 2011, perhaps as a

379 result of targeted outreach and enforcement by Fishery Officers in Campbell River (Personal

380 Communication, Joe Knight, Conservation and Protection, DFO).

381 Other factors that were not included in the model, such as local stewardship, may also affect

382 compliance. A local newspaper has printed information about the Lion's Bay RCA and residents

383 with waterfront properties bordering the RCA actively promote it. The Lion's Bay RCA is the 
D.R. Haggarty, S.J.D. Martell \& J.B. Shurin

384 only RCA in Howe Sound that had lower effort in 2007 and 2011 than in 2003. In another case, a

385 resident with waterfront property adjacent to the Mayne Island North RCA reportedly uses a

386 bullhorn to inform people fishing in that RCA of the fishing regulations and reports observations

387 to Fisheries and Oceans Canada. This RCA had less effort in 2011, while a near-by RCA, the

388 Bell Chain Islets, saw an increase in effort. Park type did not, however, affect compliance. There

389 was no difference in fishing effort among RCAs in National or Provincial Parks, or Provincial

390 Ecological Reserves and those with no additional protection. Education and enforcement by park

391 staff could improve compliance in the RCA within parks.

392 Lack of awareness about the location and regulations in the RCAs likely contributes to

393 noncompliance. No physical markers demark the boundaries of the RCAs. After an initial

394 outreach campaign associated with the Rockfish Conservation Strategy, DFO promoted the

395 RCAs with references in the Sport Fish Guide, information on its website, and signs at some boat

396 ramps. The hard copy of a booklet published about the RCAs is not widely available and fishers

397 are often directed to the internet to download an electronic copy (Fisheries and Oceans Canada

398 2008). The location of the RCAs are not readily available in any electronic form or on mapping

399 software used by sport fishers so it is difficult for a fisher to determine when they are in one.

400 This is particularly a problem in inside waters where there are numerous RCAs. Awareness of

401 the RCAs could be ameliorated by including the RCAs on nautical charts and the use of new

402 technologies such as GPS and smart phones and the development of tools (apps) that help fishers

403 to locate RCAs as well as educate them about rockfishes and regulations. No-take reserves are

404 more effective than reserves that allow some fishing (Edgar et al. 2014). Therefore, increasing

405 the level of protection to no-take reserves might also simplify the regulations, increase

406 compliance, and increase effectiveness. 
D.R. Haggarty, S.J.D. Martell \& J.B. Shurin

407 Positional accuracy of boat observations represent the greatest source of error in identifying

408 whether boats are fishing in RCAs, especially near their boundaries. Although the error

409 associated with the georeferencing process was low (root mean squared error of 16 to $30 \mathrm{~m}$ ), the

410 positional accuracy of the placement of the boat observations by the aerial survey observer

411 cannot be assessed in this study. Bias was avoided for most of the study since the boundaries of

412 the RCA were not included on the maps used in the aerial survey or during digitizing, with the

413 exception of the West Coast of Vancouver Island (WCVI) where the observer had the locations

414 of the RCAs. This region had lower instances of boats fishing in RCAs than most other regions.

415 The difference was not significant so observer bias likely had little effect on our analysis.

416 Although aerial surveys can cover much larger areas, boat-based surveys might have greater

417 positional accuracy. Smallwood and Beckley (2012) measured compliance in an Australian MPA

418 using aerial and boat-based surveys. They found that aerial and coastal surveys yielded similar

419 results; however, they identified more boats as being engaged in fishing during the boat-based

420 survey because the activity the boat operators were engaged in could not conclusively be

421 determined for $30 \%$ of their aerial observations. The aerial survey found that eight percent of

422 recreational boats were fishing in closed zones while coastal surveys found a slightly higher

423 proportion, $12 \%$, were fishing in closed zones. Our estimates of fishing effort might therefore be

424 conservative if some of the boats observed as "not fishing" were actually fishing.

425 The results of this study could be used to target outreach and enforcement activities. For

426 instance, outreach with fishing lodges could decrease effort in RCAs. Fishers who stay at lodges

427 are often not local and may be less aware of the regulations. Education and outreach activities

428 have been shown to reach a broader population than enforcement and therefore have greater

429 effects on compliance (Alder 1996, Leisher et al. 2012). An Australian study found that 
D.R. Haggarty, S.J.D. Martell \& J.B. Shurin

430 education and outreach activities such as newspaper articles and flyers, to TV and radio ads,

431 displays at boat and outdoor shows, signage at boat ramps, and education courses for tourism

432 operators and school children, had a wider impact than enforcement. The per-capita cost of

433 education was also lower than enforcement, although total education costs were greater because

434 education reaches a wider audience (Alder 1996). A study in Indonesia also found that education

435 and outreach activities resulted in greater knowledge of conservation issues and a more positive

436 attitude towards MPAs, particularly among people who were initially undecided about their

437 attitudes towards MPAs. Education and outreach did not change the attitudes of people who

438 started with negative attitudes about MPAs; therefore, a combination of education and

439 enforcement are required to change compliance levels (Leisher et al. 2012).

440 Despite the lack of compliance in many RCAs, the proportional effort in RCAs in most

441 management areas is quite low. However, some of the more heavily fished RCAs in the Southern

442 Strait of Georgia may be impacted and the Topknot RCA on the northwest coast of Vancouver

443 Island experiences at least $10 \%$ of effort in that region. Continued fishing may affect the

444 performance of such RCAs. In an age-structured model of Black Rockfish, Sethi and Hilborn

445 (2008) found that high rates of poaching negated the biological and fishery benefits of

446 implementing reserves. High rates of non-compliance in reserves have been found to limit

447 recovery of fish communities empirically as well (Campbell et al. 2012, Edgar et al. 2014,

448 McClanahan et al. 2009, McCook et al. 2010, Pollnac et al. 2010). In an Indonesian marine

449 reserve, Campbell et al. (2012) found that low compliance with no-take zones resulted in

450 decreases in fish biomass in all reserve zones despite an observed recovery in coral cover. In the

451 Great Barrier Reef, McCook at al. (2010) found that no-entry zones had a higher abundance of

452 coral trout than no-take and fishing zones. They concluded that this implied some non- 
D.R. Haggarty, S.J.D. Martell \& J.B. Shurin

453 compliance in the less strictly enforced no-take zones. In reserves in the Indian Ocean,

454 McClanahan et al. (2009) found that zones with high enforcement showed significant trends in

455 fish size and age, whereas zones with less enforcement and implied weaker compliance showed

456 lower responses. In the Mediterranean, no-take zones that were accessible by car had a lower

457 abundance of harvested sea urchins than inaccessible no-take zones (Ceccherelli et al. 2011). The

458 impacts of non-compliance may be much greater for long-lived species with low recruitment

459 rates such as rockfishes (Bergseth et al. 2013). Non-compliance in the RCAs may therefore

460 affect the performance of RCAs and may be one reason why most RCAs have not shown reserve

461 effects in an accompanying study of fish density measured with remotely operated vehicle

462 surveys inside and outside of RCAs (Haggarty 2015).

463 Compliance is critical to spatial fisheries management to promote recovery of over-exploited

464 populations (Bergseth et al. 2013, Edgar et al. 2014, Pollnac et al. 2010). Recreational fishing

465 compliance in the RCAs needs to be improved for the RCAs to conserve rockfish populations.

466 Several approaches should be taken including greater enforcement, developing a communication

467 and outreach plan (Grorud-Colvert et al. 2010), and developing tools to assist with locating the

468 RCAs. Fisheries and Oceans Canada should continue to use the fine-scale spatial information in

469 the creel survey over-flight data to monitor compliance in the RCAs and other spatial

470 management actions. In addition to assessing management actions, the model results can be used

471 to inform policy and to target enforcement and education to enhance compliance. The results

472 indicate that efforts to improve compliance with RCAs are urgently needed if they are to meet

473 their goal of contributing to recovery of rockfish populations. 
D.R. Haggarty, S.J.D. Martell \& J.B. Shurin

\section{Acknowledgements}

475 Thank you to the following Fisheries and Oceans Canada (DFO) employees for providing data

476 for this study, as well as for helpful discussions about the fishery: D. O'Brien, P. Zetterberg, B.

477 Wright, A. Pereboom, N. Olson; and C. Todd, F. Snelgrove, J. Knight, and B. Jubinville

478 (Conservation and Protection). Assistance in geo-referencing and digitizing data by A. Duran, H.

479 Chenelot and E. Chin was greatly appreciated. A review of this manuscript by N. Ban greatly

480 improved this work. This work was funded by an NSERC Strategic Grant to JBS (STPSC

$481357012-2007$ ) and an NSERC grant to SJDM. DRH was funded by an NSERC PGSB and a UBC

482 Star Fellowship. 
D.R. Haggarty, S.J.D. Martell \& J.B. Shurin

\section{References}

486 Abbott, J.K., and Haynie, A.C. 2012. What are we protecting? Fisher behavior and the

487 unintended consequences of spatial closures as a fishery management tool. Ecological

488 Applications 22(3): 762-777. doi: 10.1890/11-1319.1

489

490 Ainsworth, C.H., Morzaria-Luna, H.N., Kaplan, I.C., Levin, P.S., and Fulton, E.A. 2012. Full

491 compliance with harvest regulations yields ecological benefits: Northern Gulf of California case

492 study. J. Appl. Ecol. 49(1): 63-72. doi: 10.1111/j.1365-2664.2011.02064.x

493

494 Alder, J. 1996. Costs and effectiveness of education and enforcement, Cairns Section of the

495 Great Barrier Reef Marine Park. Environmental Management 20(4): 541-551. doi:

$496 \quad 10.1007 / \mathrm{BF} 01474654$

497

498 Arias, A., and Sutton, S.G. 2013. Understanding Recreational Fishers' Compliance with No-take

499 Zones in the Great Barrier Reef Marine Park. Ecology and Society 18(4). doi: 10.5751/es-05872-

$500 \quad 180418$

501

502 Barton, K. 2013. MuMIn: Multi-model inference. R package version 1.9.11. http://CRAN.R-

503 project.org/package=MuMIn.

504

505 Bergseth, B.J., Russ, G.R., and Cinner, J.E. 2013. Measuring and monitoring compliance in no-

506 take marine reserves. Fish and Fisheries: n/a-n/a. doi: 10.1111/faf.12051

507 
D.R. Haggarty, S.J.D. Martell \& J.B. Shurin

508 Campbell, S.J., Hoey, A.S., Maynard, J., Kartawijaya, T., Cinner, J., Graham, N.A.J., and Baird,

509 A.H. 2012. Weak Compliance Undermines the Success of No-Take Zones in a Large

510 Government-Controlled Marine Protected Area. Plos One 7(11). doi:

511 10.1371/journal.pone.0050074

512

513 Ceccherelli, G., Pais, A., Pinna, S., Sechi, N., and Chessa, L.A. 2011. Human impact on

514 Paracentrotus lividus: the result of harvest restrictions and accessibility of locations. Marine

515 Biology 158(4): 845-852. doi: 10.1007/s00227-010-1611-5

516

517 Edgar, G.J., Stuart-Smith, R.D., Willis, T.J., Kininmonth, S., Baker, S.C., Banks, S., Barrett, 518 N.S., Becerro, M.A., Bernard, A.T.F., Berkhout, J., Buxton, C.D., Campbell, S.J., Cooper, A.T., 519 Davey, M., Edgar, S.C., Forsterra, G., Galvan, D.E., Irigoyen, A.J., Kushner, D.J., Moura, R., 520 Parnell, P.E., Shears, N.T., Soler, G., Strain, E.M.A., and Thomson, R.J. 2014. Global

521 conservation outcomes depend on marine protected areas with five key features. Nature 522 506(7487): 216-220. doi: 10.1038/nature1f3022

524 English, K., Searing, G.F., and Nagtegaal, D.A. 2002. Review of the Strait of Georgia 525 Recreational Creel Survey, 1983-1999. Canadian Technical Report of Fisheries and Aquatic 526 Sciences. Fisheries and Oceans Canada.

528 ESRI. 1999-2012. ArcMap 10.1. ESRI Inc. 
D.R. Haggarty, S.J.D. Martell \& J.B. Shurin

530 ESRI. 2008. Georeferencing a raster dataset. Available from

531 http://webhelp.esri.com/arcgisdesktop/9.2/index.cfm?TopicName=Georeferencing_a_raster_data

532 set2011].

533

534 ESRI. 2012. How Kernel Density Works. Available from

535 http://resources.arcgis.com/en/help/main/10.1/index.html\#/How_Kernel_Density_works/009z00

536 000011000000/ [accessed 15-02-2013 2013].

538 Fisheries and Oceans Canada. 2008. Rockfish Conservation Areas Booklet. Available from

539 http://www.pac.dfo-mpo.gc.ca/fm-gp/maps-cartes/rca-acs/booklet-livret/index-eng.htm [accessed $540 \quad$ July 17, 2013.

541

542 Fisheries and Oceans Canada. 2012. Survey of Recreational Fishing in Canada 2010 DFO/2012-

5431804.

544

545 Fujitani, M.L., Fenichel, E.P., Torre, J., and Gerber, L.R. 2012. Implementation of a marine 546 reserve has a rapid but short-lived effect on recreational angler use. Ecological Applications 547 22(2): 597-605. doi: 10.1890/11-0603.1

549 Gaines, S.D., White, C., Carr, M.H., and Palumbi, S.R. 2010. Designing marine reserve networks 550 for both conservation and fisheries management. Proceedings of the National Academy of 551 Sciences of the United States of America 107(43): 18286-18293. doi: 10.1073/pnas.0906473107 552 
D.R. Haggarty, S.J.D. Martell \& J.B. Shurin

553 Granek, E.F., Madin, E.M.P., Brown, M.A., Figueira, W., Cameron, D.S., Hogan, Z.,

554 Kristianson, G., De Villiers, P., Williaims, J.E., Post, J., Zahn, S., and Arlinghaus, R. 2008.

555 Engaging Recreational Fishers in Management and Conservation: Global Case Studies. Conserv.

556 Biol. 22(5): 1125-1134. doi: 10.1111/j.1523-1739.2008.00977.x

558 Grorud-Colvert, K., Lester, S.E., Airamé, S., Neeley, E., and Gaines, S.D. 2010. Communicating

559 marine reserve science to diverse audiences. Proceedings of the National Academy of Sciences

560 107(43): 18306-18311. doi: 10.1073/pnas.0914292107

561

562 Haggarty, D. R. (2015). An Evaluation of the Effectiveness of Rockfish Conservation Areas in

563 British Columbia, Canada. Zoology, University of British Columbia. Ph.D. Dissertation: $218+$ 564 xix.

565

566 Hamilton, S.L., Caselle, J.E., Malone, D.P., and Carr, M.H. 2010. Incorporating biogeography

567 into evaluations of the Channel Islands marine reserve network. Proceedings of the National

568 Academy of Sciences 107(43): 18272-18277. doi: 10.1073/pnas.0908091107

570 Kritzer, J.P. 2004. Effects of noncompliance on the success of alternative designs of marine

571 protected-area networks for conservation and fisheries management. Conserv. Biol. 18(4): 1021572 1031. doi: 10.1111/j.1523-1739.2004.00022.x

573

574 Leisher, C., Mangubhai, S., Hess, S., Widodo, H., Soekirman, T., Tjoe, S., Wawiyai, S., Larsen, 575 S.N., Rumetna, L., Halim, A., and Sanjayan, M. 2012. Measuring the benefits and costs of 
D.R. Haggarty, S.J.D. Martell \& J.B. Shurin

576 community education and outreach in marine protected areas. Marine Policy 36(5): 1005-1011.

577 doi: 10.1016/j.marpol.2012.02.022

578

579 Marliave, J., and Challenger, W. 2009. Monitoring and evaluating rockfish conservation areas in

580 British Columbia. Canadian Journal of Fisheries and Aquatic Sciences 66(6): 995-1006. doi:

$581 \quad 10.1139 /$ f09-056.

582

583 McClanahan, T.R., Graham, N.A.J., Wilson, S.K., Letourneur, Y., and Fisher, R. 2009. Effects

584 of fisheries closure size, age, and history of compliance on coral reef fish communities in the

585 western Indian Ocean. Marine Ecology Progress Series 396: 99-109. doi: 10.3354/meps08279

587 McCook, L.J., Ayling, T., Cappo, M., Choat, J.H., Evans, R.D., De Freitas, D.M., Heupel, M., 588 Hughes, T.P., Jones, G.P., Mapstone, B., Marsh, H., Mills, M., Molloy, F.J., Pitcher, C.R.,

589 Pressey, R.L., Russ, G.R., Sutton, S., Sweatman, H., Tobin, R., Wachenfeld, D.R., and

590 Williamson, D.H. 2010. Adaptive management of the Great Barrier Reef: A globally significant

591 demonstration of the benefits of networks of marine reserves. Proceedings of the National

592 Academy of Sciences 107(43): 18278-18285. doi: 10.1073/pnas.0909335107

593

594 Parker, S.J., Berkeley, S.A., Golden, J.T., Gunderson, D.R., Heifetz, J., Hixon, M.A., Larson, R.,

595 Leaman, B.M., Love, M.S., Musick, J.A., O'Connell, V.M., Ralston, S., Weeks, H.J., and

596 Yoklavich, M.M. 2000. Management of Pacific rockfish. Fisheries 25(3): 22-30. doi:

$597 \quad 10.1577 / 1548-8446(2000) 0252.0 . \mathrm{CO} ; 2$. 
D.R. Haggarty, S.J.D. Martell \& J.B. Shurin

599 Pinheiro, J., Bates, D., DebRoy, S., Sarkar, D., and Team, R.D.C. 2012. nlme: Linear and

600 Nonlinear Mixed Effects Models.

601

602 Pollnac, R., Christie, P., Cinner, J.E., Dalton, T., Daw, T.M., Forrester, G.E., Graham, N.A.J., 603 and McClanahan, T.R. 2010. Marine reserves as linked social-ecological systems. Proceedings 604 of the National Academy of Sciences 107(43): 18262-18265. doi: 10.1073/pnas.0908266107. 605

607 Foundation for Statistical Computing, Vienna, Austria.

608

609 Read, A.D., West, R.J., Haste, M., and Jordan, A. 2011. Optimizing voluntary compliance in 610 marine protected areas: A comparison of recreational fisher and enforcement officer perspectives 611 using multi-criteria analysis. Journal of Environmental Management 92(10): 2558-2567. doi:

$612 \quad$ 10.1016/j.jenvman.2011.05.022.

613

614 Robb, C.K., Bodtker, K.M., Wright, K., and Lash, J. 2011. Commercial fisheries closures in 615 marine protected areas on Canada's Pacific coast: The exception, not the rule. Marine Policy 616 35(3): 309-316. doi: 10.1016/j.marpol.2010.10.010

617

618 Sethi, S.A., and Hilborn, R. 2008. Interactions between poaching and management policy affect

619 marine reserves as conservation tools. Biological Conservation 141(2): 506-516. doi:

$620 \quad 10.1016 /$ j.biocon.2007.11.005. 
D.R. Haggarty, S.J.D. Martell \& J.B. Shurin

622 Smallwood, C.B., and Beckley, L.E. 2012. Spatial distribution and zoning compliance of

623 recreational fishing in Ningaloo Marine Park, north-western Australia. Fish Res. 125: 40-50. doi:

$624 \quad$ 10.1016/j.fishres.2012.01.019.

625

626 Stelzenmüller, V., Maynou, F., Bernard, G., Cadiou, G., Camilleri, M., Crec'hriou, R., Criquet,

627 G., Dimech, M., Esparza, O., Higgins, R., Lenfant, P., and Perez-Ruzafa, A. 2008. Spatial

628 assessment of fishing effort around European marine reserves: Implications for successful

629 fisheries management. Mar. Pollut. Bull. 56(12): 2018-2026. doi:

$630 \quad 10.1016 /$ j.marpolbul.2008.08.006.

631

632 Williamson, D.H., Ceccarelli, D.M., Evans, R.D., Hill, J.K., and Russ, G.R. 2014. Derelict

633 Fishing Line Provides a Useful Proxy for Estimating Levels of Non-Compliance with No-Take

634 Marine Reserves. Plos One 9(12). doi: 10.1371/journal.pone.0114395.

635

636 Wood, S.N. 2011. Fast stable restricted maximum likelihood and marginal likelihood estimation 637 of semiparametric generalized linear models. Journal of the Royal Statistical Society. Series B

638 (Methodological) (B) 73(1): 3-36. doi: 10.1080/10618600.2012.729985.

640 Yamanaka, K., and Logan, G. 2010. Developing British Columbia’s Inshore Rockfish

641 Conservation Strategy. Marine and Coastal Fisheries: Dynamics, Management, and Ecosystem

642 Science 2: 28-46. doi: 10.1577/C08-036.1.

643 
D.R. Haggarty, S.J.D. Martell \& J.B. Shurin

644 Yoklavich, M. 1998. Marine harvest refugia for West Coast rockfish: a workshop NOAA-TM-

645 NMFS-SWFSC-255. NOAA Technical Memorandum NMFS, Pacific Grove, California.

646

647 Zetterberg, P.R., Watson, N.M., and O'Brien, D.S. 2012a. Strait of Georgia Recreational Fishery

648 Statistics for Salmon and Groundfish, 2009. Canadian Manuscript Report of Fisheries and

649 Aquatic Sciences.

650

651 Zetterberg, P.R., Watson, N.M., and O'Brien, D.S. 2012b. Strait of Georgia Recreational Fishery

652 Statistics for Salmon and Groundfish, 2010. Canadian Manuscript Report of Fisheries and

653 Aquatic Sciences.

654

655 Zar, J.H. 1996. Biostatistical Analysis. 3rd Edition. Prentice Hall, Upper Saddle River, New

656 Jersey.

657

658 Zurr, A.F., Leno, E.N., Walker, N., Savaliev, A.A., and Smith, G.M. 2009. Mixed Effects

659 Models and Extensions in Ecology with R. Springer, New York. doi: 10.1007/978-0-387-87458-

6606.

661

662 
D.R. Haggarty, S.J.D. Martell \& J.B. Shurin

666 Table 1. Number of images per region and year, positional accuracy (Root Mean Squared (RMS) 667 error) and number of fishing events observed.

Area/Year $\quad$ \# Images $\quad$ Mean RMS Error \# Fishing Events

(m)

\begin{tabular}{lccc}
\hline Strait of Georgia 2003 & 575 & 20.2 & 18,778 \\
Strait of Georgia 2007 & 581 & 15.9 & 11,734 \\
Strait of Georgia 2011 & 727 & 30.1 & 14,551 \\
N. Vancouver I. & 55 & 16.9 & 4,660 \\
2011 & & & 15,499 \\
SW. Vancouver I. 2011 & NA & NA & 65,222 \\
Total & 1938 & & \\
\hline
\end{tabular}


D.R. Haggarty, S.J.D. Martell \& J.B. Shurin

674 Table 2. Results of the preferred linear mixed effects model (AIC=1379) using 462 observations 675 and 77 groups (RCAs). Degrees of freedom calculated with Satterthwaite approximations.

\begin{tabular}{llllllll}
\hline Fixed Effects & Value & $\begin{array}{l}\text { Std. } \\
\text { Error }\end{array}$ & DF & t-value & p-value & $2.5 \%$ & $97.5 \%$ \\
& & & & & & CI & CI \\
\hline Intercept & 356.6 & 35.7 & 382.3 & 10.0 & $<0.001^{*}$ & 286.6 & 1.3 \\
Year & -0.2 & 0.02 & 382.3 & -9.9 & $<0.001^{*}$ & -0.2 & -0.1 \\
Treatment & -280.8 & 50.6 & 382.3 & -5.5 & $<0.001^{*}$ & -379.8 & -181.9 \\
Year*Treatment & 0.1 & 0.03 & 382.3 & 5.5 & $<0.001^{*}$ & 0.1 & 0.2 \\
\hline
\end{tabular}

676 
D.R. Haggarty, S.J.D. Martell \& J.B. Shurin

679 Table 3. Summary of changes in monthly recreational effort with time by RCA.

\begin{tabular}{lcr}
\hline Change in Effort & \# of RCAs & \% \\
\hline No Change, Effort in all years & 30 & 39.0 \\
No Change, No Effort & 14 & 18.2 \\
No Change, Low Effort ${ }^{\dagger}$ & 20 & 26.0 \\
Increase in 2007* & 2 & 2.6 \\
Increase in 2011* & 3 & 3.9 \\
Decrease in 2007* & 2 & 2.6 \\
Decrease in 2011* & 1 & 1.3 \\
Decrease in 2007 and $2011^{*}$ & 5 & 6.5 \\
\hline Total & 77 & 100.0 \\
\hline
\end{tabular}

680

$681 *$ Monthly effort in some RCAs increased or decreased $(\mathrm{p}<0.05)$.

$682 \dagger$ We characterized RCAs with $0.01-0.5$ boats per $\mathrm{km}^{2}$ as having low effort. 
D.R. Haggarty, S.J.D. Martell \& J.B. Shurin

684

685

686 Table 4. Explanatory variables that were retained and rejected in the best model (deviation

687 explained $75.7 \%$, adjusted $\mathrm{R}^{2}$ of $\left.0.67, \mathrm{n}=105\right)$.

\begin{tabular}{llll}
\hline Model Variable & Retained in Model & F & p \\
\hline Fishing Effort Density in 2km Buffer & Yes & 8.0 & $<0.0001$ \\
Size $\left(\mathrm{km}^{2}\right)$ & Yes & 31.6 & $<0.0001$ \\
Enforcement (Patrol hrs/Stat Area) & Yes & 6.1 & $<0.0001$ \\
Distance to Fishing Lodge (km) & Yes & 3.6 & 0.001 \\
Perimeter-Area Ratio (PA) & Yes & 4.0 & 0.006 \\
Distance to City (km) & No & & \\
Rockfish Catch (per Stat Area) & No & & \\
Population within 25 km radius & No & & \\
Region (factor) & No & & \\
\hline
\end{tabular}

688

689

690 
D.R. Haggarty, S.J.D. Martell \& J.B. Shurin

692 Figure 1. Study area of Southern British Columbia showing the Rockfish Conservation Areas

693 (RCAs) on and off of the aerial survey flight path and Pacific Fishery Management Areas (11-

694 29) (PFMA).

695

696 Figure 2. Boxplot of standardized $\log +1$ fishing effort density inside and outside of RCAs in

697 2003, 2007, and 2011. Two extreme outliers are not shown.

699 Figure 3. Proportion of recreational effort in RCAs in the Strait of Georgia by management area

700 (PFMA) by year. PFMA 15 is not shown due to a change in the flight pattern over one large

701 RCA.

702

703 Figure 4. The density effort in 2007 minus 2003 (top) and 2011 minus 2007 (bottom). Blue

704 colors indicate lower effort in the later year while warmer colors indicate higher effort. Most

705 RCAs are shown in grey indicating no change in effort.

707 Figure 5. Fishing effort probability around Vancouver Island along RCAs on the flight path and

$7082 \mathrm{~km}$-wide buffers, as well as the location of fishing lodges and cities (population $>5,000$ ). Insets

709 show RCAs in the southern and northern extents of Vancouver Island. 
D.R. Haggarty, S.J.D. Martell \& J.B. Shurin

712 Figure 6. Five significant variables were retained in the RCA Compliance Generalized Additive

713 Model. Plots show the smooths of the significant variables. Shaded regions are two standard

714 error confidence bands for smooths and the points are partial residuals. Region (lower right) was

715 not retained in the model despite an overall significant difference among regions; however, a

716 multiple comparison test showed that Effort Density in RCAs was only lower in the Mid-Strait

717 of Georgia (MSOG) than in the Campbell River (CR) and Queen Charlotte Strait (QCS) regions. 
D.R. Haggarty, S.J.D. Martell \& J.B. Shurin

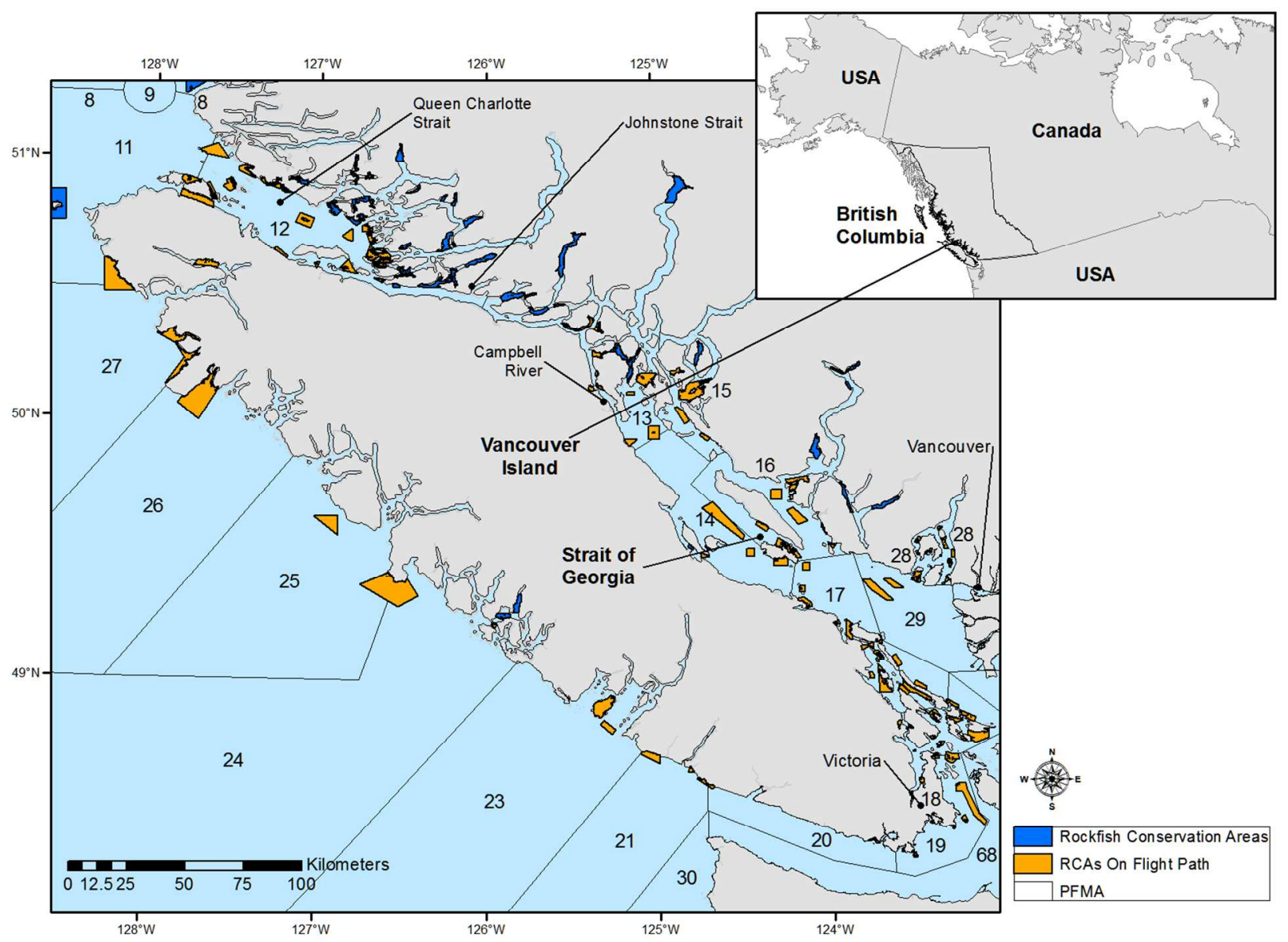

724 Figure 1. Study area of Southern British Columbia showing the Rockfish Conservation Areas

725 (RCAs) on and off of the aerial survey flight path and Pacific Fishery Management Areas (11- 
D.R. Haggarty, S.J.D. Martell \& J.B. Shurin

728

729

730

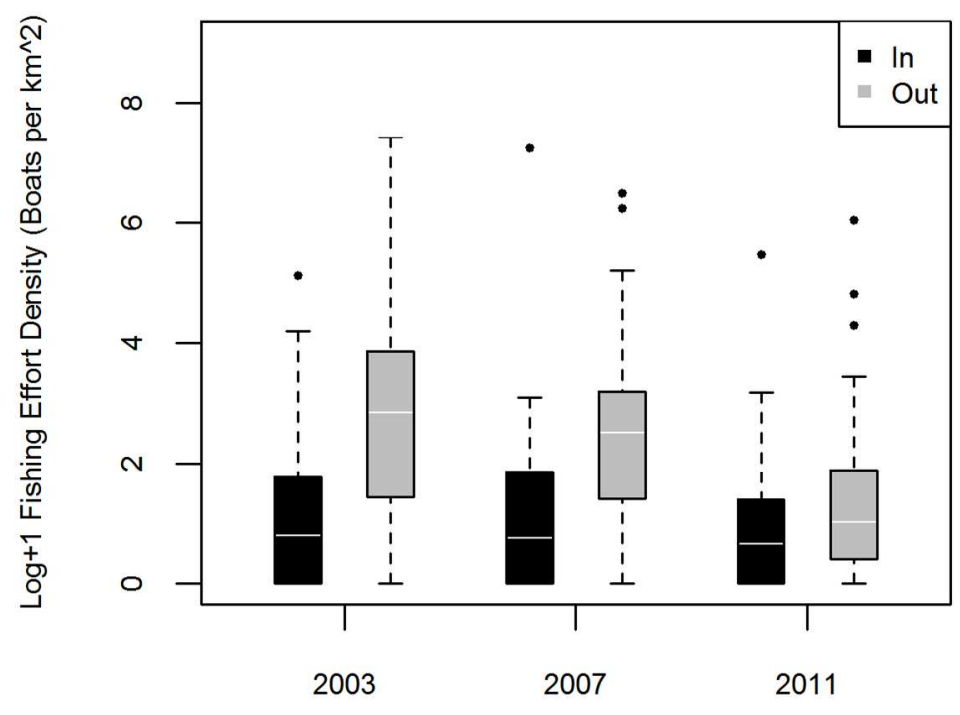

731

Year

732 Figure 2. Boxplot of standardized $\log +1$ fishing effort density inside and outside of RCAs in

733 2003, 2007, and 2011. Two extreme outliers are not shown. 
D.R. Haggarty, S.J.D. Martell \& J.B. Shurin

736

737

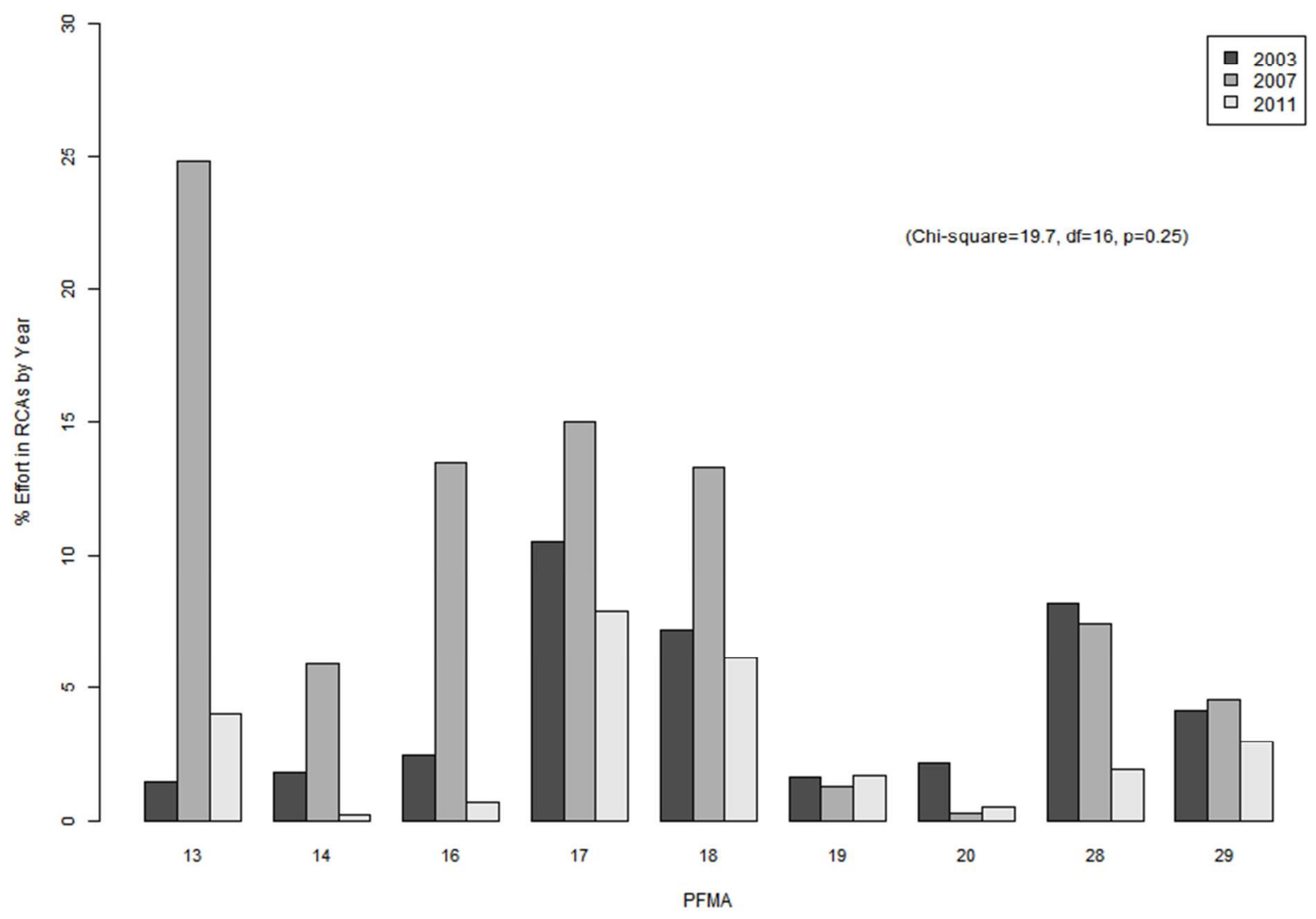

739 Figure 3. Proportion of recreational effort in RCAs in the Strait of Georgia by management area

740 (PFMA) by year. PFMA 15 is not shown due to a change in the flight pattern over one large

741 RCA.

742 
D.R. Haggarty, S.J.D. Martell \& J.B. Shurin

743
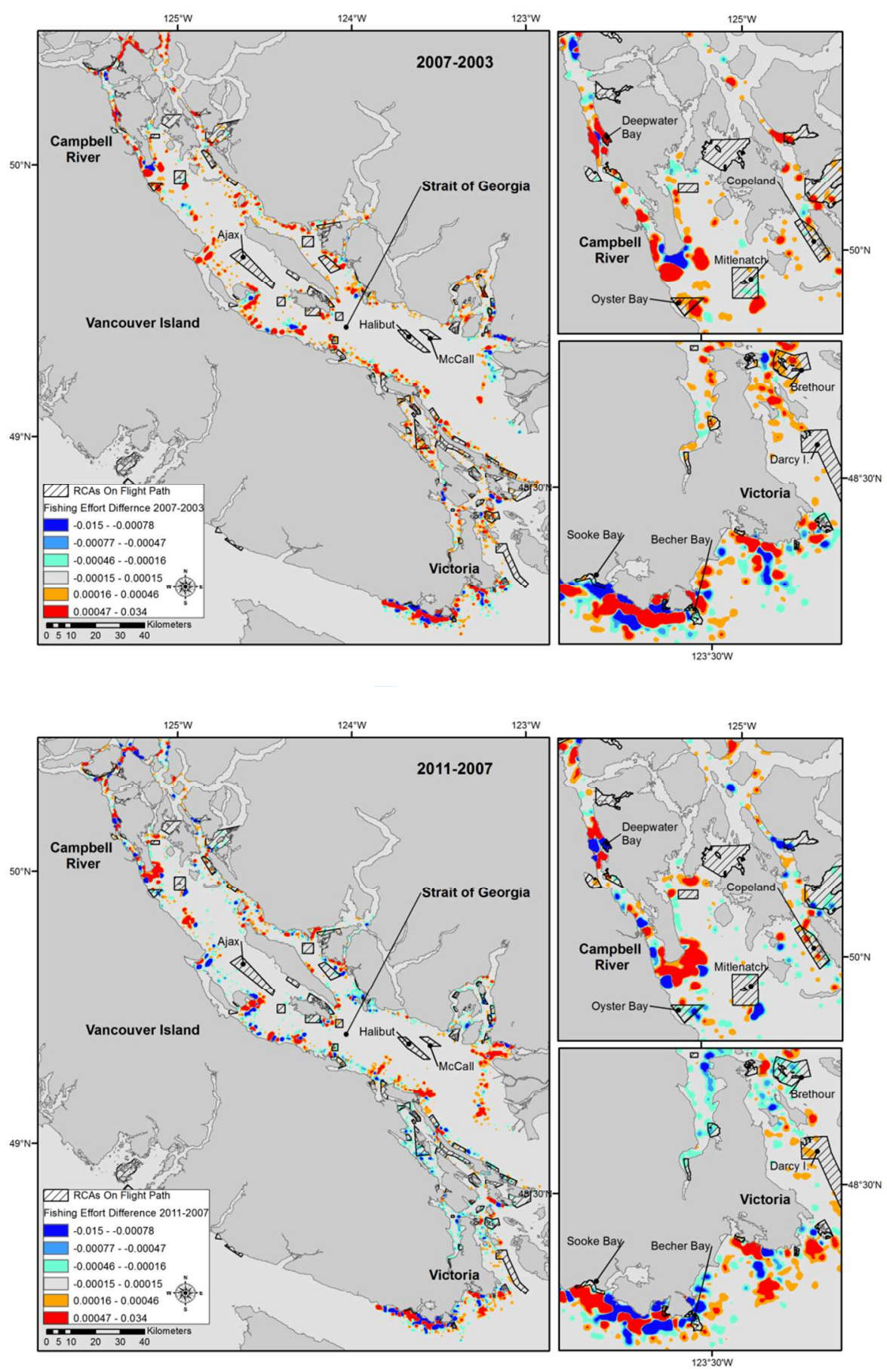

744

745 Figure 4. The density effort in 2007 minus 2003 (top) and 2011 minus 2007 (bottom). Blue

746 colors indicate lower effort in the later year while warmer colors indicate higher effort. Most

747 RCAs are shown in grey indicating no change in effort. 
D.R. Haggarty, S.J.D. Martell \& J.B. Shurin
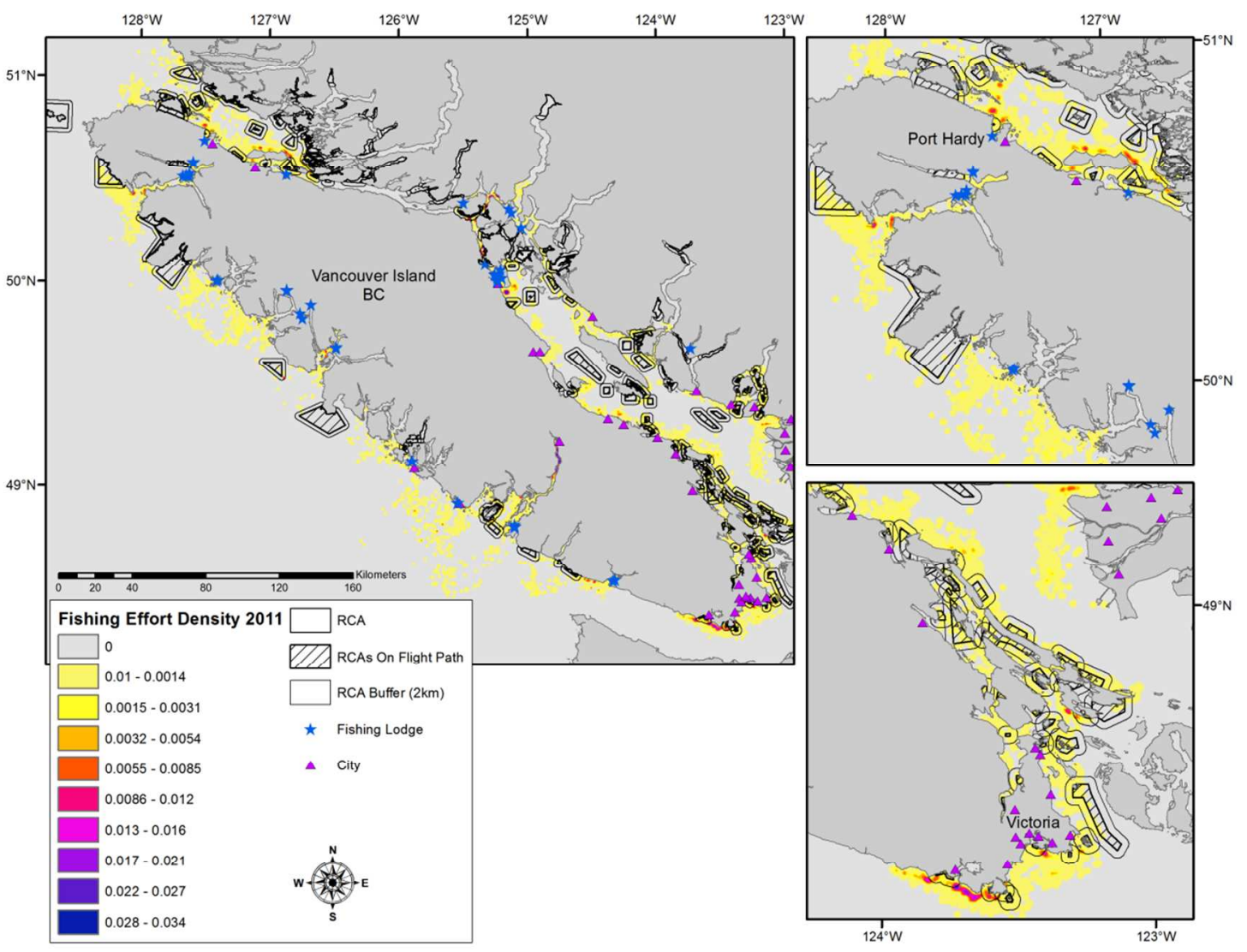

753 Figure 5. Fishing effort probability around Vancouver Island along RCAs on the flight path and

$7542 \mathrm{~km}$-wide buffers, as well as the location of fishing lodges and cities (population $>5,000$ ). Insets

755 show RCAs in the southern and northern extents of Vancouver Island. 
D.R. Haggarty, S.J.D. Martell \& J.B. Shurin
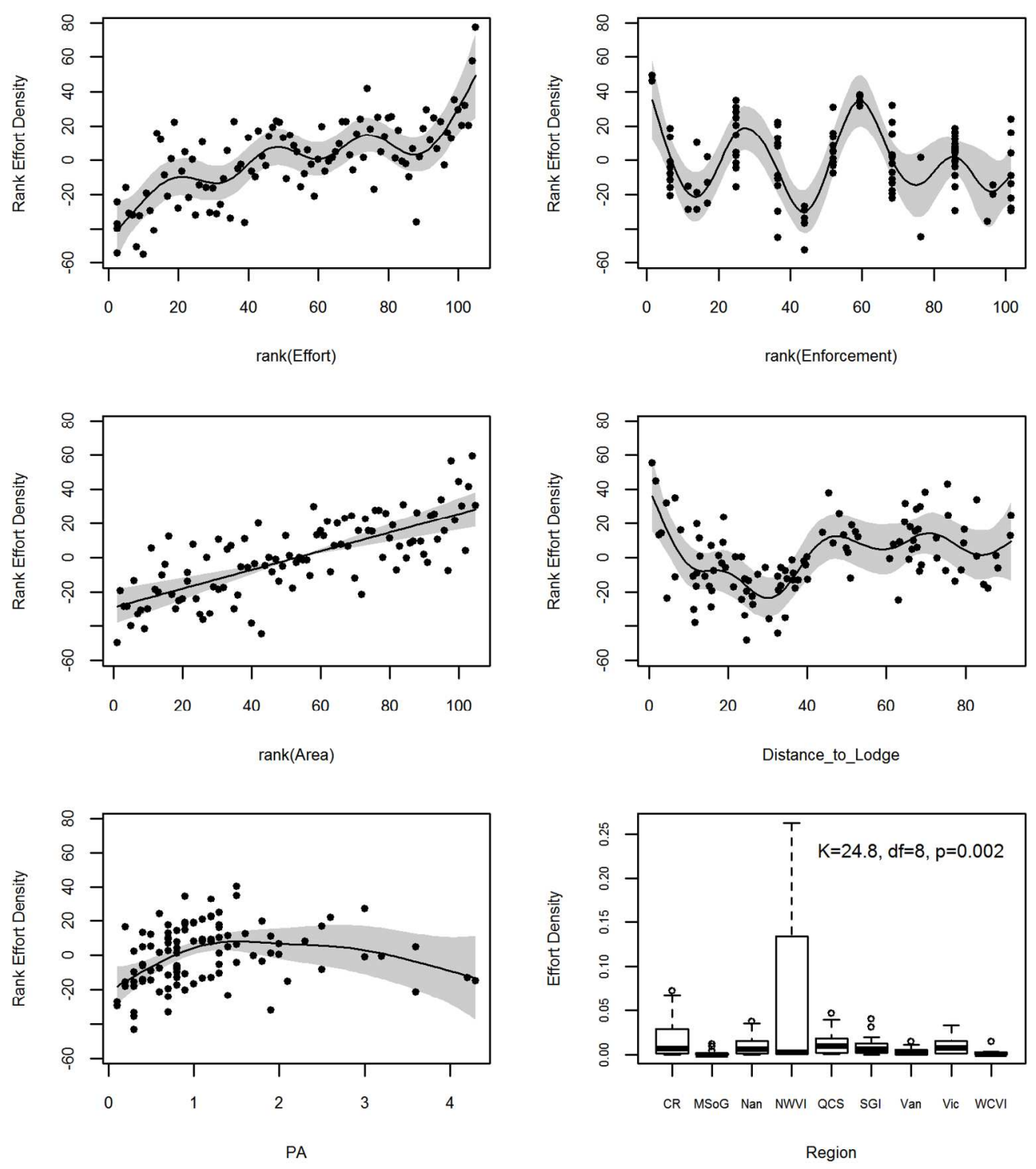

758 Figure 6. Five significant variables were retained in the RCA Compliance Generalized Additive

759 Model. Plots show the smooths of the significant variables. Shaded regions are two standard

760 error confidence bands for smooths and the points are partial residuals. Region (lower right) was

761 not retained in the model despite an overall significant difference among regions; however, a

762 multiple comparison test showed that Effort Density in RCAs was only lower in the Mid-Strait

763 of Georgia (MSOG) than in the Campbell River (CR) and Queen Charlotte Strait (QCS) regions. 
Supplement Table 1. Model Variable data sources and GIS calculations.

\begin{tabular}{|c|c|c|c|}
\hline Variable & Data & GIS Calculation & Transformation \\
\hline City & Towns with Population $>5000$ & $\begin{array}{l}\text { Distance Nearest to RCA } \\
\text { "Near function" }\end{array}$ & None \\
\hline Fishing Lodge & $\begin{array}{l}\text { Google Earth Fishing lodge } \\
\text { locations. }\end{array}$ & $\begin{array}{l}\text { Distance Nearest to RCA- } \\
\text { Near Function }\end{array}$ & None \\
\hline $\begin{array}{l}\text { Rockfish catch } \\
\text { (rfcatch) }\end{array}$ & $\begin{array}{l}\text { Creel survey estimate of the } \\
\text { total number of rockfish caught } \\
\text { per creel area, May-September } \\
2011 \text { (data from D. O'Brien, } \\
\text { South Coast Management, } \\
\text { DFO). }\end{array}$ & Spatial Join with RCAs & None \\
\hline $\begin{array}{l}\text { Effort Density } \\
\text { Adjacent to RCA } \\
(2 \mathrm{~km} \text { Buffer })\end{array}$ & $\begin{array}{l}\text { Normalized Kernel Density } \\
\text { analysis (2011) }\end{array}$ & $\begin{array}{l}\text { Sum per } 2 \mathrm{~km} \text { buffer strip } \\
\text { around each RCA using } \\
\text { Zonal Statistics tool, } \\
\text { divided by area of buffer. }\end{array}$ & Rank \\
\hline $\begin{array}{l}\text { Enforcement } \\
\text { (patrol hours) }\end{array}$ & $\begin{array}{l}\text { Numbers of hours each } \\
\text { Conservation and protection } \\
\text { field unit spent on the water in } \\
\text { each statistical area in } 2011 \\
\text { (data from C. Todd, } \\
\text { Conservation and Protection, } \\
\text { DFO). }\end{array}$ & Spatial Join with RCA & Rank \\
\hline $\begin{array}{l}\text { Population within } 25 \\
\mathrm{~km} \text { radius of each } \\
\mathrm{RCA}\end{array}$ & $\begin{array}{l}2011 \text { Census data joined to } \mathrm{BC} \\
\text { place names }\end{array}$ & $\begin{array}{l}\text { Spatial Join to calculate } \\
\text { the sum of population } \\
\text { within } 25 \mathrm{~km} \text { of each RCA }\end{array}$ & Rank \\
\hline RCA Area (size) & $\mathrm{RCA}$ & Calculate geometry $\left(\mathrm{km}^{2}\right)$ & Rank \\
\hline $\begin{array}{l}\text { Perimeter to Area } \\
\text { Ratio (PA) }\end{array}$ & RCA shapefile & $\begin{array}{l}\text { I created a } 1 \mathrm{~cm} \text {-buffer } \\
\text { around each RCA, erased } \\
\text { the RCA from it, to have } \\
\text { an RCA perimeter. I then } \\
\text { erased the shoreline so that } \\
\text { I would only have the } \\
\text { perimeter of the RCA that } \\
\text { was fronted by water. I } \\
\text { divided the open perimeter } \\
\text { by the area of the RCA. }\end{array}$ & None \\
\hline Regions & 9 regions & $\begin{array}{l}\mathrm{RCA} \text { assigned to the factor } \\
\text { region }\end{array}$ & None \\
\hline
\end{tabular}




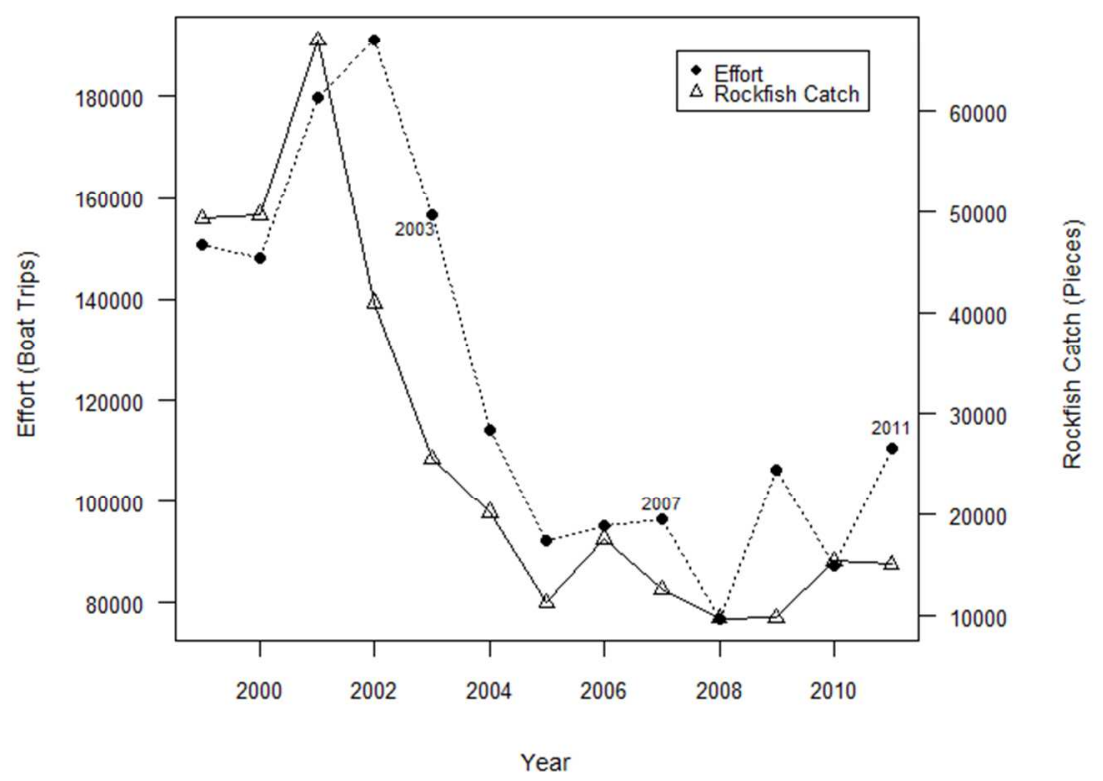

Supplement Figure 1. Recreational Fishing Effort and estimated total Inshore Rockfish catch (number of fish) in the Strait of Georgia 1999-2011. Data shown are from Zetterberg et al. (2012). Data from 2011 were provided by P. Zetterberg, South Coast Management, DFO. The years addressed in this study, 2003, 2007 and 2011 are highlighted. Inshore rockfish recreational catch, which is estimated from the Creel Survey effort data and dockside interviews closely tracks the effort. 


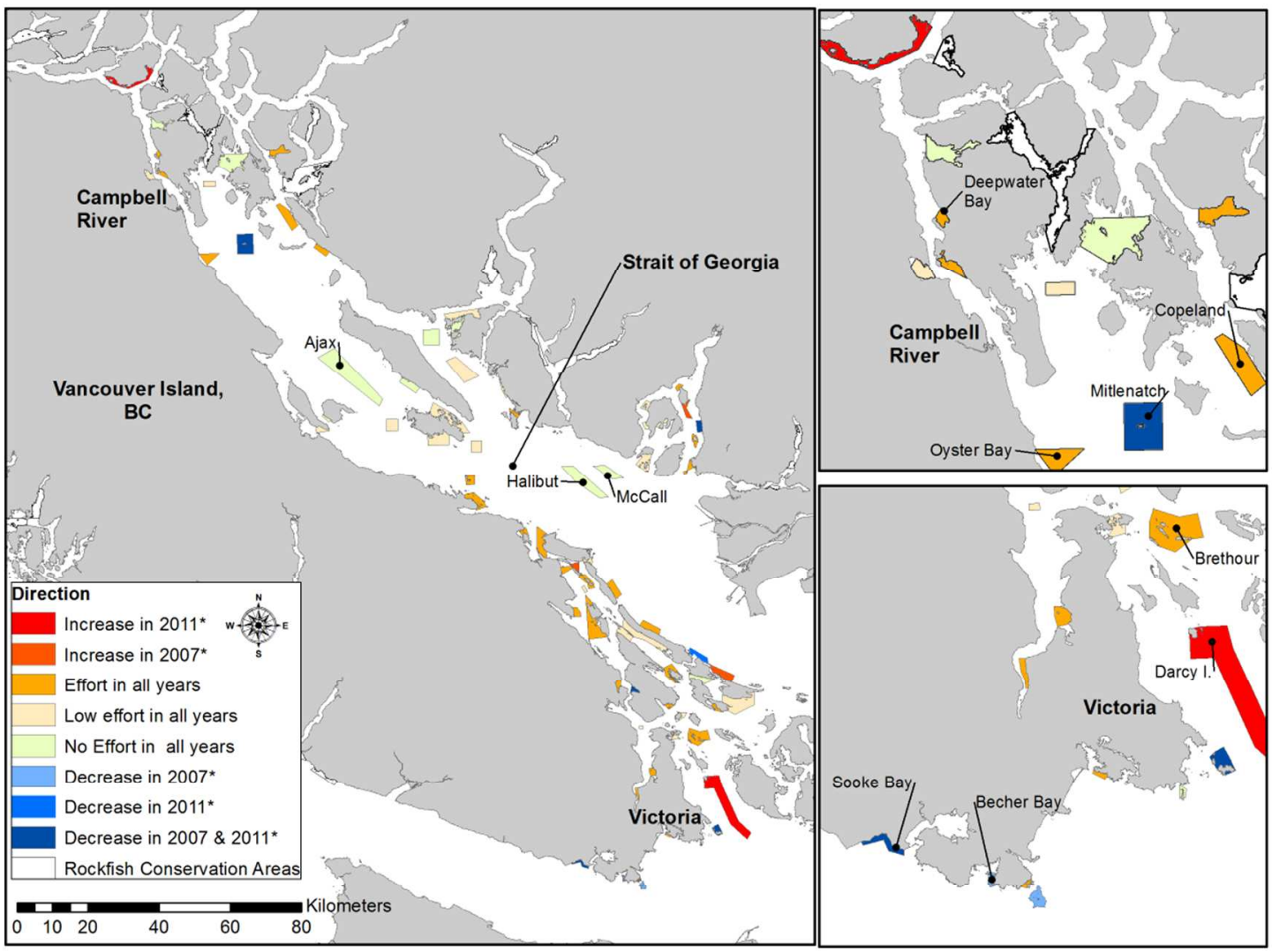

Supplement Figure 2. Changes in monthly recreational effort with time by RCA. Increases and decreases of effort (*) are RCAs with significant differences in effort while the other RCAs showed no significant difference in effort with time. RCAs with $<0.5$ boats per $\mathrm{km}^{2}$ were characterized with low effort while RCAs with $>0.5$ boats per $\mathrm{km} 2$ were characterized as having effort. 
Supplement Table 2. Mean monthly fishing effort per RCA by Year with ANOVA test statistic $(\mathrm{F})$ and probability using the bonferroni correction $(\mathrm{df}=2)$. For years with different effort, Tukey multiple comparison test results are shown.

\begin{tabular}{|c|c|c|c|c|c|c|c|}
\hline RCA & 2003 & 2007 & 2011 & $\mathrm{~F}$ & $\mathrm{p}$ & Direction & $\begin{array}{l}\text { Tukey Multiple } \\
\text { Comparisons }\end{array}$ \\
\hline Ajax & 0.0 & 0.0 & 0.0 & & & Zero all years & \\
\hline Davie & 0.0 & 0.0 & 0.0 & & & Zero all years & \\
\hline Halibut & 0.0 & 0.0 & 0.0 & & & Zero all years & \\
\hline Kanish & 0.0 & 0.0 & 0.0 & & & Zero all years & \\
\hline Mariners & 0.0 & 0.0 & 0.0 & & & Zero all years & \\
\hline McCall & 0.0 & 0.0 & 0.0 & & & Zero all years & \\
\hline $\begin{array}{l}\text { McNaughton } \\
\text { Navy }\end{array}$ & 0.0 & 0.0 & 0.0 & & & Zero all years & \\
\hline Channel & 0.0 & 0.0 & 0.0 & & & Zero all years & \\
\hline Nelson & 0.0 & 0.0 & 0.0 & & & Zero all years & \\
\hline Read & 0.0 & 0.0 & 0.0 & & & Zero all years & \\
\hline Sinclair & 0.0 & 0.0 & 0.0 & & & Zero all years & \\
\hline $\begin{array}{l}\text { Trial } \\
\text { Upper }\end{array}$ & 0.0 & 0.0 & 0.0 & & & Zero all years & \\
\hline Centre & 0.0 & 0.0 & 0.0 & & & Zero all years & \\
\hline West Bay & 0.0 & 0.0 & 0.0 & & & Zero all years & \\
\hline Lasqueti & 0.2 & 0.2 & 0.0 & 3.7 & 0.06 & low effort all years & \\
\hline Malaspina & 0.0 & 0.1 & 0.0 & 3.3 & 0.07 & low effort all years & \\
\hline Gabriola & 0.3 & 0.0 & 0.0 & 2.7 & 0.11 & low effort all years & \\
\hline Pasley & 0.3 & 0.0 & 0.1 & 2.2 & 0.16 & low effort all years & \\
\hline Saltspring & 0.0 & 0.1 & 0.4 & 2.2 & 0.16 & low effort all years & \\
\hline Sabine & 0.2 & 0.3 & 0.0 & 1.8 & 0.20 & low effort all years & \\
\hline Saturna & 0.2 & 0.4 & 0.1 & 1.5 & 0.26 & low effort all years & \\
\hline Menzies & 0.5 & 0.0 & 0.3 & 1.3 & 0.30 & low effort all years & \\
\hline Portland & 0.0 & 0.2 & 0.0 & 1.0 & 0.39 & low effort all years & \\
\hline $\begin{array}{l}\text { Chrome } \\
\text { Danger }\end{array}$ & 0.1 & 0.0 & 0.0 & 1.0 & 0.40 & low effort all years & \\
\hline Reefs & 0.3 & 0.0 & 0.0 & 1.0 & 0.40 & low effort all years & \\
\hline Heriot & 0.4 & 0.0 & 0.0 & 1.0 & 0.40 & low effort all years & \\
\hline Patey & 0.5 & 0.0 & 0.0 & 1.0 & 0.40 & low effort all years & \\
\hline Savoie & 0.3 & 0.0 & 0.0 & 1.0 & 0.40 & low effort all years & \\
\hline Sisters & 0.0 & 0.0 & 0.0 & 1.0 & 0.40 & low effort all years & \\
\hline Woolridge & 0.0 & 0.3 & 0.0 & 1.0 & 0.40 & low effort all years & \\
\hline Young & 0.0 & 0.0 & 0.1 & 1.0 & 0.40 & low effort all years & \\
\hline Trincomali & 0.1 & 0.3 & 0.4 & 0.8 & 0.48 & low effort all years & \\
\hline Coal & 0.1 & 0.3 & 0.0 & 0.6 & 0.58 & low effort all years & \\
\hline Hardy & 0.2 & 0.2 & 0.1 & 0.3 & 0.72 & low effort all years & \\
\hline
\end{tabular}




\begin{tabular}{|c|c|c|c|c|c|c|c|}
\hline $\mathrm{RCA}$ & 2003 & 2007 & 2011 & $\mathrm{~F}$ & $\mathrm{p}$ & Direction & $\begin{array}{l}\text { Tukey Multiple } \\
\text { Comparisons }\end{array}$ \\
\hline Darcy & 0.0 & 0.0 & 0.2 & 19.0 & 0.00 & increase in 2011 & $\begin{array}{l}2011>2003,2007 \\
(0.007,0.003) \\
2011>2003,2007\end{array}$ \\
\hline Walken & 0.1 & 0.0 & 1.9 & 5.6 & 0.02 & increase in 2011 & $\begin{array}{l}(0.04,0.03) \\
2007>2003(0.00005),\end{array}$ \\
\hline Pam Rock & 0.0 & 3.1 & 0.4 & 25.7 & 0.00 & increase in 2007 & $\begin{array}{l}2011<2007(0.004), \\
2011=2003 \\
2007>2003(0.01),\end{array}$ \\
\hline Bell Chain & 0.2 & 1.3 & 0.6 & 6.3 & 0.01 & increase in 2007 & $\begin{array}{l}2011=2003,2007 \\
2007>2003,2011\end{array}$ \\
\hline De Courcy & 0.0 & 0.3 & 0.0 & 5.8 & 0.02 & increase in 2007 & $(0.03,0.03)$ \\
\hline Coffin & 2.2 & 1.4 & 0.2 & 3.6 & 0.06 & effort & \\
\hline Brethour & 0.1 & 1.0 & 0.4 & 3.6 & 0.06 & effort & \\
\hline Ruxton & 0.4 & 0.7 & 0.1 & 3.0 & 0.09 & effort & \\
\hline Bowyer & 4.3 & 1.1 & 1.1 & 2.9 & 0.10 & effort & \\
\hline Reynolds & 0.0 & 0.8 & 0.0 & 2.8 & 0.10 & effort & \\
\hline Russell & 0.0 & 0.0 & 1.3 & 2.6 & 0.12 & effort & \\
\hline Brentwood & 3.8 & 2.0 & 1.3 & 2.6 & 0.12 & effort & \\
\hline $\begin{array}{l}\text { West Van } \\
\text { Mid }\end{array}$ & 2.8 & 1.5 & 0.4 & 2.5 & 0.12 & effort & \\
\hline Finlayson & 0.2 & 1.4 & 0.2 & 2.3 & 0.14 & effort & \\
\hline Nanoose & 1.1 & 0.5 & 0.9 & 2.0 & 0.18 & effort & \\
\hline Thetis & 1.0 & 1.7 & 0.8 & 1.9 & 0.19 & effort & \\
\hline Thormanby & 0.9 & 0.0 & 0.0 & 1.9 & 0.19 & effort & \\
\hline Domett & 0.0 & 0.6 & 0.2 & 1.5 & 0.27 & effort & \\
\hline Prevost & 0.6 & 0.1 & 0.2 & 1.0 & 0.39 & effort & \\
\hline Departure & 0.9 & 0.0 & 0.6 & 1.0 & 0.39 & effort & \\
\hline Duntze Head & 1.8 & 0.0 & 0.0 & 1.0 & 0.40 & effort & \\
\hline Galiano & 1.0 & 0.4 & 1.0 & 1.0 & 0.40 & effort & \\
\hline Passage & 0.0 & 0.0 & 1.2 & 1.0 & 0.40 & effort & \\
\hline Maple & 1.4 & 0.1 & 0.4 & 1.0 & 0.40 & effort & \\
\hline Deepwater & 11.8 & 55.5 & 47.8 & 0.9 & 0.42 & effort & \\
\hline $\begin{array}{l}\text { Maud } \\
\text { Northumber- }\end{array}$ & 0.7 & 0.8 & 3.7 & 0.8 & 0.46 & effort & \\
\hline land & 0.7 & 0.4 & 0.3 & 0.7 & 0.50 & effort & \\
\hline Copeland & 0.6 & 0.2 & 0.4 & 0.7 & 0.51 & effort & \\
\hline Teakerne & 0.2 & 0.7 & 0.2 & 0.7 & 0.52 & effort & \\
\hline Ballenas & 1.0 & 1.5 & 0.8 & 0.6 & 0.58 & effort & \\
\hline Oyster & 0.2 & 0.8 & 0.3 & 0.6 & 0.58 & effort & \\
\hline Bentinck & 0.8 & 0.0 & 2.2 & 0.5 & 0.60 & effort & \\
\hline Valdes & 1.4 & 1.4 & 1.4 & 0.3 & 0.78 & effort & \\
\hline Bedwell & 0.8 & 0.5 & 0.5 & 0.1 & 0.94 & effort & \\
\hline Dinner Rock & 0.6 & 0.4 & 0.8 & 0.0 & 0.99 & effort & \\
\hline
\end{tabular}




\begin{tabular}{|c|c|c|c|c|c|c|c|}
\hline $\mathrm{RCA}$ & 2003 & 2007 & 2011 & $\mathrm{~F}$ & $\mathrm{p}$ & Direction & $\begin{array}{l}\text { Tukey Multiple } \\
\text { Comparisons }\end{array}$ \\
\hline Mayne & 4.0 & 1.4 & 0.3 & 4.9 & 0.03 & decrease in 2011 & $2011<2003(0.02)$ \\
\hline Race Rocks & 5.6 & 0.7 & 2.1 & 5.8 & 0.02 & decrease in 2007 & $\begin{array}{l}2007<2003(0.01), \\
2011=2003,2007 \\
2007<2003(0.03)\end{array}$ \\
\hline \multirow[t]{2}{*}{$\begin{array}{l}\text { Becher } \\
\text { Sooke }\end{array}$} & 33.7 & 1.0 & 4.6 & 4.6 & 0.03 & decrease in 2007 & $\begin{array}{l}2011=2003,2007 \\
2011(0.0002)\end{array}$ \\
\hline & 13.1 & 1.1 & 0.4 & 21.7 & 0.00 & decrease & $\begin{array}{l}2007(0.0004)<2003 \\
2007,2011<2003\end{array}$ \\
\hline Lions Bay & 10.4 & 1.2 & 0.6 & 18.9 & 0.00 & decrease & $\begin{array}{l}(0.001,0.0003) \\
2007,2011<2003\end{array}$ \\
\hline Mitlenatch & 1.0 & 0.0 & 0.0 & 14.1 & 0.00 & decrease & $\begin{array}{l}(0.002,0.001) \\
2011\end{array}$ \\
\hline Burgoyne & 4.4 & 1.0 & 0.8 & 5.5 & 0.02 & decrease & $\begin{array}{l}2007(0.04,0.03)<2003 \\
2007,2011<2003\end{array}$ \\
\hline Discovery & 1.0 & 0.0 & 0.0 & 5.3 & 0.02 & decrease & $(0.04,0.04)$ \\
\hline
\end{tabular}



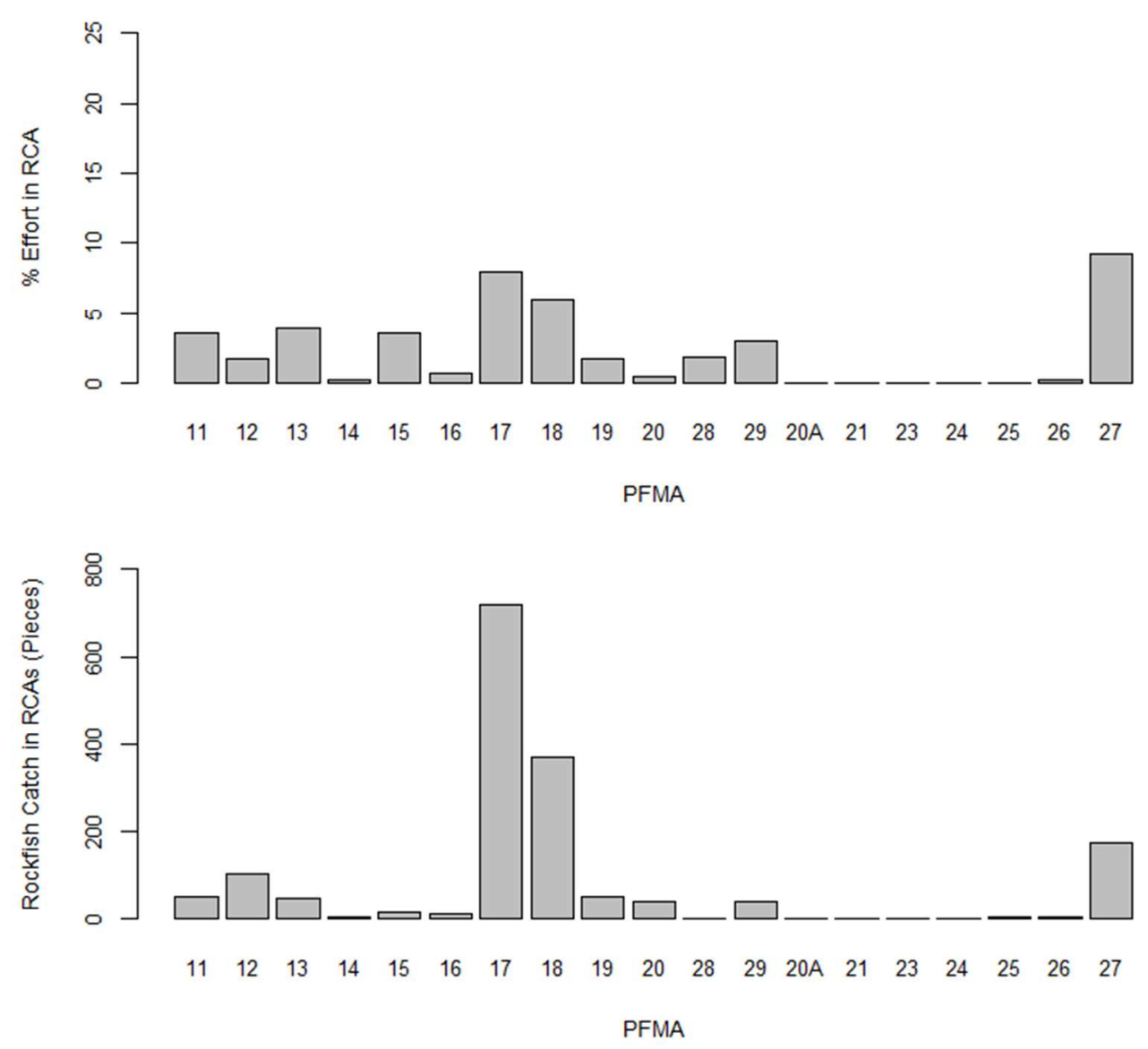

Supplement Figure 3. Relative fishing effort (\%) in RCAs by Pacific Fishery Management Areas (PFMA). This proportion was applied to the estimated rockfish catch by PFMA in 2011 to estimate the number of rockfish that could have been taken in the recreational fishery in RCAs in each PFMA. Areas 17 and 18 (near Nanaimo and the Gulf Islands), has the highest estimated rockfish catch, followed by area 27, NW Vancouver Island. 